\title{
Alkaline Anion Exchange Membranes for Fuel Cells- a Patent
}

\section{Review}

\author{
Rong Zeng and John R. Varcoe** \\ Division of Chemical Sciences, The University of Surrey, Guildford GU2 7XH United Kingdom
}

\begin{abstract}
Recently, Alkaline Polymer Electrolyte Membrane Fuel Cells (APEMFCs) have been attracting worldwide attention mainly due to the prospect of using non-platinum-group metal catalysts. In addition, there is growing evidence that these fuel cells can operate with the presence of carbonate. This mini review will introduce the state-of-the-art in understanding of alkaline anion-exchange membranes (AAEMs) in solid alkaline fuel cells. Ionomers for membrane electrode assembly (MEA) fabrication and the chemistry of the carbonate and bicarbonate forms of the AAEMs are also discussed. Key references to the latest scientific literature and reviews are included, along with a brief overview of directly relevant patents.
\end{abstract}

Keywords: Alkaline polymer electrolyte membrane fuel cell, alkaline anion exchange membrane, alkaline ionomer, hybrid membrane fuel cell, carbonate and bicarbonate.

\section{INTRODUCTION}

Fuel cells are recognized as a key technology in the delivery of clean energy for a future sustainable society. Many advanced materials and technologies have been developed over the past few decades. Despite fuel cell engine cars being demonstrated worldwide, widespread commercialization of fuel cell technology suffers from continuous delays. There is a current lack of hydrogen infrastructure resulting in higher costs when using hydrogen, while Proton Exchange Membrane Fuel Cells (PEMFC) themselves are still very expensive compared to internal combustion engines; the cost is primarily because PEMFCs are highly dependent on Pt-based catalyst (due to the presence of an acidic, low $\mathrm{pH}$, environment) although the cost of other key components such as the bipolar plate and the proton

\footnotetext{
* Corresponding author. Tel.: +44 (0)1483 682616. Email: j.varcoe@ surrey.ac.uk( J Varcoe)
} 
exchange membranes are also significant (these are anticipated to be reduced with the onset of the mass manufacture). A major benefit of Alkaline Fuel Cell (AFC) technologies is the ability to use cheaper, more abundant, non-platinum catalysts. The hydroxide $\left(\mathrm{OH}^{-}\right)$anions, however, will convert to mixtures of carbonate $\left(\mathrm{CO}_{3}{ }^{2-}\right)$ and bicarbonate $\left(\mathrm{HCO}_{3}^{-}\right)$anions when air (containing carbon dioxide) is used as the oxidant; the main issue with this is the solubility of carbonate and bicarbonate salts, which are low, and this leads to the risk of precipitation in the electrode pores and therefore fuel cell failure [1]. This highlights the importance of developing alkaline polymer electrolytes where the polymerbound cationic groups, such as quaternary ammonium, $\left(\mathrm{R}^{\prime}-\mathrm{NR}_{3}{ }^{+}\right)$groups, prevent carbonate/bicarbonate salt precipitation (the polymer electrolytes are, and operate, in the solid state) [2] There is also growing evidence of their ability to operate in the presence of carbonate anions [3-5]. Recently, the successful application of non-platinum catalysts in both the cathode and the anode of an alkaline polymer electrolyte membrane fuel cells (APEMFC) have been reported [6]. Investigations into the use of non-hydrogen fuels, such as methanol and the "higher" alcohols (e.g. ethanol, isopropanol and ethylene glycol) [7], glucose [8], hydrazine $\left(\mathrm{H}_{2} \mathrm{NNH}_{2}\right)$ [9], ammonia [10], urea (urine) [11] and borohydride $\left(\mathrm{BH}_{4}{ }^{-}\right)$[12] have been studied in APEMFCs. The potential of APEMFCs has spurred on the worldwide search for, and development of, mechanically, chemically and thermally stable alkaline anion exchange membranes (AAEM). Anion-exchange membranes have even been evaluated in biological fuel cell systems containing enzymes [13] and microbes (Microbial Fuel Cells) [14-15].

AAEMs (and alkaline ionomers - see later) are key materials required for the successful implementation of APEMFCs. Anion-exchange membranes (that are not always alkali stable) have, for a long time, been used as separation membranes for seawater desalination, the recovery of metal ions from wastewaters, electrodialysis and bio-separation processes. There are many inventions [e.g. 16-26] that use anion-exchange membranes for desalination and electrodialysis. These membranes however may be not stable or conductive enough to be applied in APEMFCs. AAEMs used in early APEMFC studies were reviewed in 2005 [27] and included polybenzimidazole (PBI) doped with $\mathrm{KOH}$, epichlorhydrine polymer quaternized with 1,4-diazabicyclo[2,2,2]octane (DABCO) or quaternized with a 1:1 ratio of DABCO and triethylamine, and commercial membranes such as AHA (Tokuyama Co, Japan), Morgane ADP (Solvey S.A.), and Tosflex ${ }^{\circledR}$ SF-17 (Tosoh) and 2259-60 (Pall RAI). Most 
of these fuel cells containing AAEMs were being operated with the presence of aqueous alkaline solutions $(\mathrm{NaOH}$ or $\mathrm{KOH})$.

In our group, we have successfully developed several kinds of quaternary-ammonium-containing radiation-grafted AAEMs based on poly(vinylidene fluoride) PVDF [28-32], poly(tetrafluroethyleneco- hexafluoropropylene) FEP [28,29,33] and poly(ethylene-co-tetrafluoroethylene) ETFE [34-35] with good ion exchange capacities (IEC) and ionic conductivities and with sufficient stabilities to test the proof of concept of using AAEMs in fuel cells. We found that ETFE base films produced the best AAEMs for testing in APEMFCs. Note that these AAEMs were not developed with commercialization in mind: the materials cost for making the ETFE based AAEMs are $<\$ 150 / \mathrm{m}^{2}$ when purchase chemicals on the lab scale. The radiation-grafted methodology allowed for the production of AAEMs of different thicknesses, ion-exchange capacity, physical / mechanical properties, and chemistries that facilitated fundamental investigations. To partially solve the membrane-electrode interface problem (i.e. the lack of available alkaline analogues to the Nafion ${ }^{\circledR}$ dispersions used in PEMFCs) we developed a water insoluble alkaline ionomer that used $N, N, N^{\prime}, N^{\prime}$-tetramethylhexane-1,6-diamine as the joint amination and cross-linking agent and we reported on the performance of metal-cation-free all-solidstate alkaline fuel cells with medium-term performance stability [34,36]. Many other groups have developed new conductive and chemically and thermally stable AAEMs (and alkaline ionomers). This review will focus on the state-of-the-art development on AAEMs, including patents and the primary scientific literature, and will highlight the important issues regarding the use of AAEMs in APEMFCs.

\section{PREPARATION OF ALKALINE ANION-EXCHANGE MEMBRANES (AAEM)}

A good AAEM will have a high ion-exchange capacity, high ion conductivity and thermochemical stability but will exhibit low degrees of swelling (especially in water and alcohols). There are several general synthetic methodologies for the preparation of AAEMs [37-38]. The easiest is using inert polymers doped with concentrated aqueous KOH: Polybenzimidazole (PBI) [39-43], poly(vinyl alcohol) (PVA) [44], composite polymers such as PVA/hydroxyapatite (PVA/HAP) [45], quaternizedPVA/alumina (QPVA/ $\left./ \mathrm{Al}_{2} \mathrm{O}_{3}\right)$ [46], PVA/titanium oxide $\left(\mathrm{PVA} / \mathrm{TiO}_{2}\right)$ [47-48], chitosan and cross-linked chitosan [49-51], copolymers of epichlorohydrin and ethylene oxide [52], and cross-linked PVA/sulfosuccinic acid (10 wt.\% SSA) [53] have all been doped with KOH and used as AAEMs. The invention US5569559 [54] describes the use of polar polymers (most preferred being polyethylene 
oxide) doped with alkaline metal hydroxides (such as $\mathrm{KOH}$ ), alkaline-earth metal hydroxides or ammonium hydroxides such as tetrabutylammonium hydroxide. PBI doped with KOH showed the highest conductivity which was comparable to $\mathrm{Nafion}^{\circledR}$ (a well known acidic polymer electrolyte membrane / proton-exchange membrane).

The preparation of applicable AAEMs normally involves a compromise between the properties of the membrane, such as the chemical and thermal stability, ion exchange capacity (IEC), ion conductivity, mechanical properties, water uptake and dimensional stability. Key details on the preparation of fuel cell relevant AAEMs except by the doping method is summarized in Table 1 (delineated by polymer backbone and/or active (exchange) functional group chemistry). In general, alkaline anion exchange polymer electrolytes can be polymerized directly from functionalized monomers, polymerized from monomers with subsequent functionalization or by functionalizing a commercially available polymer. The backbone of the polymer is usually selected for its good chemical and thermal stability and, therefore, typically includes aromatic rings and/or a degree of fluorination: Typical polymers classes include polysulfones and polyetherketone (and derivatives thereof), polyimides, poly(phenylene), poly(phthalazinon ether sulfone ketone), polyepichlorhydrin homopolymer, polybenzimidazole (PBI), poly(phenyleneoxide), radiation-grafted copolymers, inorganic-organic hybrids, and even perfluoronated membranes such as Nafion ${ }^{\circledR}$. The active functional groups are commonly quaternary ammonium type $\left(-\mathrm{NR}_{3}^{+}\right)$with a clear preference for trimethylammonium $\left(-\mathrm{N}\left(\mathrm{CH}_{3}\right)_{3}{ }^{+}\right)$groups $\left(\mathrm{NMe}_{3}, \mathrm{pKa}\left(\mathrm{H}_{2} \mathrm{O}\right)=9.8\right)$.

As described in US20040023110 [55], it is easy to produce cross-linked poly(vinylbenzyltrimethylammonium hydroxide) (PVBTMAOH) from the functional monomer such as vinylbenzyltrimethylammonium chloride (VBTMACl) by adding a cross-linking agent such as N,N'-bismethyleneacrylamide (BMAAm) and using an azo free radical initiator such as 2.2'-azobis(2-methylpropionamidine) dihydrochloride. This cross-linked PVBTMAOH, which is insoluble in water, can be used as AAEM in APEMFCs. Using 4-vinylpyridine as start monomer, a 4-vinylpyridine-based alkaline anion exchange membrane polymerized by plasma polymerization has also been reported [56].

Tokuyama is one of the leading companies on the commercial front of alkaline anion exchange membranes (e.g. their AHA membrane). Their thin $(10 \mu \mathrm{m})$ "fuel cell grade" AAEMs (A010, A201 formally A006, and A901) [57-61] and dispersible alkaline ionomers (A3ver.2 and AS-4) [62-64] have 
been tested by different research groups. They deserved a few words to show their alkaline electrolyte direct polymerized from different monomers.

In GB1401997 [16] , Tokuyama Soda Kabushiki Kaisha (probably Tokuyama) claimed anion exchange membranes which contained cation exchange groups (sulphonic acid) on the surface of membrane to reduce contamination by organic matter (biofouling) during the desalination of water. An example membrane was synthesized by coating a paste onto a cloth of poly(vinyl chloride) (PVC) and both coated surfaces were bonded to a film of PVA; the paste consisted of divinylbenzene, styrene, PVC powder, dioctylphthalate and benzoyl peroxide. The assembly was heated for 4 hours at $120^{\circ} \mathrm{C}$ to form a base membrane. The base membrane was sulphonated by sulphuric acid followed by chloromethylation (treated with chloromethyl ether) and quaternization/amination (treated with trimethylamine) to form an alkaline membrane. More recently, Tokuyama have applied for a series of patents [65-72] regarding the production of solid alkaline anion exchange polymer electrolytes, membranes and alkaline electrodes for fuel cells. More specifically, WO2009148051 [70] claimed an anion conductive resin, containing a quaternary onium [sic] salt with at least part of counter ions of being $\mathrm{CO}_{3}{ }^{2-}$ and/or $\mathrm{HCO}_{3}{ }^{-}$, which was used as a binder in the electrocatalyst layer of the electrodes. WO2010041641 [71] claimed an anion exchange membranes with either quaternary ammonium or quaternary phosphonium groups. A membrane for direct liquid fuel cells, described in US20100104920 [72], consisted of a porous film with the pores filled with a cross-linked hydrocarbon based anion exchange resin; the preferred porous film was a polyolefin. A polymerizing monomer with a halogen alkyl group (e.g. chloromethylstyrene), a cross-linking polymerizable monomer, an epoxy groupcontaining compound, and an effective amount of polymerization initiator was contacted with the porous films having a thickness of 5 to $60 \mu \mathrm{m}$ for the pore filling process; the formulations were then polymerized in situ and cured. The halogen alkyl group possessed by the resin obtained post-curing was finally converted into a quaternary ammonium functional group. An example of the polymerizing composition is as follows: $p$-chloromethylstyrene (100\%mass), divinylbenzene (5\% mass), tert-butyl peroxyethylhexanoate (5\% mass), and an epoxy compound (Epolite 40E: ethylene glycol diglycidyl ether, $5 \%$ mass).

A widespread strategy for the synthesis of AAEMs is to introduce halogenalkyl groups onto the backbone or side chains of the polymer via chloroalkylation, fluorination, bromination or chlorination (depending on the base polymer or the desired polymer structure) followed by amination/quaternization 
and finally ion exchange. One strategy is to use a monomer that is already functionalized with halogenalkyl group or tertiary amine groups. Highly carcinogenic chloromethylethers have traditionally been used as the chloroalkylation agent, as chloromethylation of polymers is commonly observed for AAEM synthesis, but safer strategies have been introduced, e.g. the chloromethylation agent is generated in situ of the reaction with the polymer e.g. [74-76]. Wang et al. [77] studied the effect of parameters such as the reaction temperature, reaction time, concentration of the chloromethylation agent, polymer concentration, and amount of the catalyst for the chloromethylation of a poly(ether imide). They found that the concentration of chloromethylation agent, such as chloromethylether (CME), played an important role. This poly(ether imide)-based AAEMs showed good chemical stability in aqueous $\mathrm{KOH}\left(1 \mathrm{~mol} \mathrm{dm}{ }^{-3}\right)$, however, the conductivity was too low for application (ca. 3 $\mathrm{mS} \mathrm{cm}{ }^{-1}$ ) [78]. An alternative strategy is for the introduction of tertiary amine groups onto the polymer first, instead of chloroalkylation, followed by quaternization to produce quaternary ammonium anion exchange groups; the quaternizing agent used include methyl chloride, methyl iodide, methyl bromide, ethyl chloride, ethyl iodide, ethyl bromide, propyl chloride, propyl iodide, propyl bromide or $\mathrm{CF}_{3} \mathrm{SO}_{3} \mathrm{CH}_{3}$, with toxic methyl iodide being the most preferred option. To lower the usage of toxic organic reagents like the chloromethylation agent, many researchers use the monomers that already contain chloromethyl or tertiary amine groups for AAEM synthesis. An exemplar synthesis of an AAEM based on polysulfone, one of the aromatic ring polymers (polyaromatics / polyarylenes), is highlighted in Scheme 1 [79].

The amine/ammonium groups are often connected to the backbone of the polymer via alkyl or aryl bridges. However, there is a class of AAEMs containing tertiary aliphatic diamines, polyamines or other cationic species that are coupled to a support/base polymer via $-\mathrm{SO}_{2}-$ linkages [80-83]. The $\mathrm{SO}_{2}-$ groups are introduced using sulphonation reactions with reagents such as sulphonic acid or acidic halides (a thionyl halide, preferably thionyl chloride). Monomers containing amine groups can then react with the sulfonated polymer, to form the links, and then there is a final quaternization process. The AAEMs with these sulphoamide linked sidegroups containing quaternary ammoniums, such as $N, N, N^{\prime}, N^{\prime}$-tetramethyl-1,3-propanediamine-modified sulfonated ETFE-g-poly(styrene) membrane, often show better stability in aqueous alkali solutions (such as $\mathrm{NaOH}$ ) and better ionic conductivity than AAEMs with the cationic functional groups coupled to the polymer via alkyl links, such as trimethylamine-quaternized ETFE-g-VBC membranes [80-81]. A Nafion precursor polymer, which 
contains $-\mathrm{SO}_{2} \mathrm{~F}$ groups, has also been used to prepare a new AAEM by chemically attaching proazaphosphatranium/phosphatranium cations under microwave treatment to the sulfonic groups of Nafion-F [82].

Anion-exchange polymers that contain methacrylate, ester, amide or other carbonyl $(\mathrm{C}=\mathrm{O}$ double bond) containing groups (some examples in Table 1) will show low stabilities in alkali as these functional groups are highly reactive to nucleophiles such as $\mathrm{OH}^{-}$. Recent research and modeling studies also suggest that the stability of the base polymer is not enough to obtain stable AAEMs. There are several chemical degradation mechanisms for ammonium-based anion-exchange groups in the presence of hydroxide[27]: The Hoffmann elimination reactions (when $\beta$-hydrogen atoms are present), direct nucleophilic displacements, degradation involving ylide intermediates (evidence provided from deuterium exchange experiments) and ylide-induced rearrangement reactions such as Stevens and Sommelet-Hauser rearrangements (for polymers containing benzyltrimethylammonium functional groups) $[84,85]$. There is also evidence from a number of independent studies that AAEMs based on alkyl pyridinium groups are a poor choice [86,87] (pyridinium group has particular low basicity pyridine $\mathrm{pKa}=5.2$ ); generally trimethylammonium cations are considered to be more stable than $\mathrm{N}$ methylpyridinium cations. By studying the stability of model compounds such as tetramethylammonium hydroxide pentahydrate, Macomber et al. [84] suggest that ammonium cations may be more stable than expected but only when the functional groups are well hydrated. Vega et al. [88] studied four commercially available AAEMs and confirmed the Hofmann elimination and nucleophilic displacement mechanisms. DABCO $\left(\mathrm{pKa}\left(\mathrm{H}_{2} \mathrm{O}\right)=8.8\right)$ and quinuclidine have been researched as the use of these quaternization agents have been suggested to minimize the quaternary ammonium degradation reactions mentioned above [89] despite them containing $\beta$-hydrogen atoms; this is because the $\mathrm{C}-\mathrm{H}_{\beta}$ bonds are in the incorrect conformation to the $\mathrm{C}-\mathrm{N}_{\text {quat }}$ bonds for efficient Hofmann elimination (which requires anti-periplanar conformations). Similarly, $N, N_{,} N^{\prime}, N^{\prime}-$ tetramethylhexane-1,6-diamine contains $\beta$-hydrogen atoms but quaternary ammonium groups formed from this diamine, or containing hexyloxy spacer groups, are reported to be quite stable as the electron density around the $\beta$-hydrogen atoms is not favorable for Hofmann elimination reactions [90-91]. However, highly charged (doubly charged) diamines are likely to show low chemical stabilities.

Compared to Nafion ${ }^{\circledR}$ proton-exchange membranes, the ion conductivity of AAEMs are generally lower. This is not surprising as the mobility of $\mathrm{OH}^{-}$is $1 / 3-1 / 2$ of that of a $\mathrm{H}^{+}$(depending on the 
environment and if there is an electric field present $-\mu_{o} \times 10^{4} / \mathrm{cm}^{2} \mathrm{~V}^{-1} \mathrm{~s}^{-1}=20.64$ for $\mathrm{OH}^{-}(\mathrm{aq})$ anions and 36.23 for $\mathrm{H}^{+}(\mathrm{aq})$ cations at $298 \mathrm{~K}$, which translate into diffusion coefficients of $D \times 10^{9} / \mathrm{m}^{2} \mathrm{~s}^{-1}=$ 5.30 and 9.31 respectively using the Nernst-Einstein equation) [1, 92]. One strategy for enhanced ionic conductivities is to increase the IEC, but this often leads to a decrease in the mechanical properties due to the excessive water uptakes. Another strategy is to synthesize tailored membranes that will exhibit hydrophilic(iononic)-hydrophobic(non-ionic) phase segregation (tethered exchange groups) and continuous ionic domains, which is hypothesized to increase ionic conductivities [76, 93]. Hickner's work on Proton Exchange Membrane (PEM) show there is a complex interaction of polymer morphology, water motion and ion content that contribute to ion transport [94]. By independently varying the hydrophobic and hydrophilic portions of the molecules, the self-assembly of the ionic groups, ion-conduction, and mechanical support can be tuned. Hibbs and co-worker's [73] recent work (refer to Table 1) report a functionalized copolymer DAPP-ATMPP (DAPP-TMPP is the copolymer of bCPD (bis(cyclopentadienone)) and TMbCPD, which is produced by 4,4'-dimethylbis(benzyl ketone) and 4-phenylglyoxalylbenzil, and DAPP-ATMPP is the DAPP-TMPP copolymer funtionalized with quaternary ammonium groups ), where the hydrophobic block DAPP was added deliberately and which exhibited improved ion conductivity and mechanical properties than the homopolymer ATMPP. It has suggested that the use of ionic and nonionic blocks would drive the formation of hydrophilic and hydrophobic domains within the membrane and contribute to better ion conductivity. Hibbs et al. [73] also claimed that the irregularities in linearity of poly(phenylene) backbone and bulky side groups, which prevent efficient packing of the polymer, facilitate the ion conductivity. Tertiary aliphatic diamines or polyamines [80-81,95-96] are often used to increase the concentration of ion exchange groups with concomitant cross-linking to maintain the mechanical properties of the membrane. Park et al. [96] found that AAEM synthesized using tertiary aliphatic diamines with longer alkyl chains (i.e. 6 carbon alkyl chains) shows better ion conductivities and thermal stabilities (as mentioned above). Tanaka et al. [97] investigated high molecular weight aromatic polymers with rigid and bulky fluorenyl groups to introduce more ionic groups and to achieve higher IECs (> $\left.2.5 \mathrm{meq} \mathrm{g}^{-1}\right)$; ion conductivities were promising at $50 \mathrm{mS} \mathrm{cm}{ }^{-1}$ at room temperature with reasonable water uptakes. Other researchers have focused on monomers containing groups with high basicity, from reactions with pentamethylguanidine [98-99] $\left(\mathrm{pKa}\left(\mathrm{H}_{2} \mathrm{O}\right) \sim 14\right)$, 1,1,3,3-tetramethylguanidine (TMG) [100], and tertiary phosphine [101-102] $\left(\mathrm{pKa}\left(\mathrm{H}_{2} \mathrm{O}\right) \sim 8.0\right)$; the ion conductivity of the resulting AAEM with 
quaternary guanadinium groups was $67 \mathrm{mS} \mathrm{cm}^{-1}$ at $20^{\circ} \mathrm{C}\left(\mathrm{IEC}=2.15 \mathrm{meq} \mathrm{g}^{-1}\right)$. Kong et al. [82] studied proazaphosphatranium cation, attached to the Nafion ${ }^{\circledR}$ via a S-P bond, which exhibit reduced charge densities due to the different resonance structures that distribute the positive charge, and diminish ionic interactions, and which should facilitate hydroxide ion mobility; however no IEC and ion conductivity data were reported. Imidazolium-type ionic liquids, such as 1-allyl-3-methylimidazolium chloride [103], have also been used to introduce anion exchange group into polymers. Such membranes show good ion conductivities of up to $33 \mathrm{mS} \mathrm{cm}^{-1}$ at $30^{\circ} \mathrm{C}$.

Fluorine-containing polymers generally show higher thermal stabilities than hydrocarbon polymers. Wang and coworkers [104] developed a soluble partial fluorinated polysulfone anion exchange polymer which showed a remarkable ion conductivity in excess of $60 \mathrm{mS} \mathrm{cm}^{-1}$ alongside a low swelling ratio of $33 \%$ at $20^{\circ} \mathrm{C}$; however, the swelling ratio was too high $(123 \%)$ at $60^{\circ} \mathrm{C}$. AAEMs based on a poly(arylene ether sulfone) containing fluorine groups showed high ion conductivities (63 $\mathrm{mS} \mathrm{cm}{ }^{-1}$ in $\mathrm{CO}_{3}{ }^{2-}$ form at $70^{\circ} \mathrm{C}-$ this is an amazing result as $\mathrm{CO}_{3}{ }^{2-}$ anions have dilute solution mobilities that are less than $33 \%$ of $\mathrm{OH}^{-}$anions and it is rare to see $\mathrm{CO}_{3}{ }^{2-}$ conductivities above $30 \mathrm{mS}$ $\mathrm{cm}^{-1}$ ) [105]. These last two results suggest that fluorine atoms on polyarylene backbones benefit ion conductivity. A note of caution on a conflict in nomenclature: References [97] and [105] both mention fluorenyl groups but which relate to totally different chemistries (one containing $\mathrm{CF}_{3}$ groups and one containing non-fluorinated aromatic ring systems).

Organic-inorganic composite membranes synthesized using the sol-gel process is an alternative class of AAEM being actively investigated. The cross-links and the inorganic component, such as -O$\mathrm{Si}-\mathrm{O}-$, are hypothesized to increase the thermal stability of the resulting AAEMs. Tripathi et al. [106] and $\mathrm{Xu}$ and coworkers [107-112], Liu and coworkers [113-114], and Suzuki et al. [115] have all focused on organic-inorganic composite anion exchange membranes. Commonly encountered amines containing inorganic monomers, such as aminoethylaminopropylmethyldimethoxysilane [115], alkylated triethoxysilylpropylamine (TESPA (+)) [110] and an anion exchange precursor labelled AESP [106] (see Table 1), clearly highlight the preference for resultant silicon containing inorganicorganic hybrids. A PPO-based composite membrane quaternized with triethylamine (TEA) [107-108] showed good ion conductivity $\left(11 \mathrm{mS} \mathrm{cm}^{-1}\right.$ ) and produced a power density of $32 \mathrm{~mW} \mathrm{~cm}$ (geometric) $^{-2}$ when tested in a $\mathrm{H}_{2} / \mathrm{O}_{2}$ fuel cell (gases supplied at ambient pressure). 
Coates and co-workers [93,116] developed a ring-opening metathesis polymerization synthetic route for the preparation of AAEMs. The cross-linked membrane (containing unsaturated $\mathrm{C}=\mathrm{C}$ bonds in the polymer backbone) showed record $\mathrm{OH}^{-}$conductivities $\left(>150 \mathrm{mS} \mathrm{cm}^{-1}\right.$ at $90^{\circ} \mathrm{C}$ as measured using 4-probe impedance techniques) with low swelling ratios; the membrane polymerized using cyclooctene (COE) and tetraalkylammonium-functionalized cross-linkers [93] exhibit almost the same ion conductivity as Nafion 112 between $20^{\circ} \mathrm{C}-90^{\circ} \mathrm{C}$ in $\mathrm{OH}^{-}$anion form. These recent results suggest strongly that the ion conductivities of $\mathrm{OH}^{-}$form AAEMs have been previously underestimated. However, the stability of polymers containing unsaturated $\mathrm{C}=\mathrm{C}$ bonds is a concern. Coates and coworkers have now reported a tetraalkylammonium-functionalized polyethylene of where the $\mathrm{C}=\mathrm{C}$ bonds have been removed by hydrogenation using Crabtree's catalyst ([[COD]Ir(Py)(PCy $\left.\left.\mathrm{PC}_{3}\right) \mathrm{PF}_{6}\right)$ and hydrogen gas [117]. The resulting polymer can be cast to form an AAEM and can be dissolved in aqueous n-propanol for use as an ionomer.

Irradiation of polymer films (and powders etc.) using $\gamma$-rays, $x$-rays and electron beams is a flexible way to introduce various functional groups on the polymer backbones. As irradiation produces a copious number of active sites in the polymer, it is a versatile way to functionalize (or cross-link) polymers. Detailed information on irradiation-induced copolymerization of polar and functional monomer onto non-polar polymeric films can be found in the comprehensive review by Nasef and Hegazy [118]. A wide range of chemically and thermal stable polymers can be chosen as the base films for the production of AAEMs. Patents [80-81, 119-122] use $\gamma$-rays irradiation, while other work such as at the University of Surrey [28-35] also uses electron beam irradiation. Stable polymers such as ETFE and FEP have been used to produce AAEMs using this irradiation grafting methodology. Additionally, there is a wide choice of functional monomers available that can be used to introduce ion-exchange groups into the grafted polymeric chains. The radical and peroxy-type active groups on the irradiated polymer have been confirmed to be stable at low temperatures [123] (after a sharp decrease during the first day) and the IECs of ETFE-based AAEMs have been shown statistically to be invariant even after the irradiated ETFE has been stored for 160 days at $-40^{\circ} \mathrm{C}$ before grafting [124]. An outline of, and example of, this synthetic methodology of such radiation-grafted-AAEMs is illustrated in Scheme 2 [34]. An AAEM produced from $20 \mu \mathrm{m}$ thick ETFE was evaluated in a $\mathrm{H}_{2} / \mathrm{O}_{2}$ fuel cell and yielded beginning-of-life peak power densities of $230 \mathrm{~mW} \mathrm{~cm}{ }^{-2}$ (geometric) and current densities above $1300 \mathrm{~A} \mathrm{~cm}^{-2}[125]$. 
Besides the polymer membranes above, inorganic materials like layered perovskite-type oxides such as $\mathrm{LaSr}_{3} \mathrm{Fe}_{3} \mathrm{O}_{10}, \mathrm{NaLaTiO}_{4}, \mathrm{Sr}_{4} \mathrm{Co}_{1.6} \mathrm{Ti}_{1.4} \mathrm{O}_{8}(\mathrm{OH})_{2} \times \mathrm{xH}_{2} \mathrm{O}, \mathrm{RbLaNb}_{2} \mathrm{O}_{7}, \mathrm{LaFeO}_{3}$ [126] and $\mathrm{NaCo}_{2} \mathrm{O}_{4}$ [127129] have been used as electrolyte in alkaline fuel cell. The study of these new inorganic electrolyte membranes is still in its infancy. The power density of $64 \mathrm{mWcm}^{-2}$ at $80^{\circ} \mathrm{C}$ for direct ethanol fuel cell was achieved using $\mathrm{NaCo}_{2} \mathrm{O}_{4}$ thin film as electrolyte, $\mathrm{Fe}-\mathrm{Co}-\mathrm{Ni} / \mathrm{C}$ as anode catalyst and a catalyst free cathode [128]. This is a promising result and shows that inorganic membranes are promising for use in alkaline membrane fuel cells.

\section{THE APPLICATION OF ALKALINE ANION-EXCHANGE MEMBRANES IN FUEL CELLS}

The main interest in using an AAEM as an electrolyte in a fuel cell is the prospect for the use of non-Pt group metal (non-PGM) catalysts, cheaper fuel cell components (less corrosive environment), and alternative fuels. Alcohols and diols, sodium borohydride $\left(\mathrm{NaBH}_{4}\right)$ and hydrazine $\left(\mathrm{H}_{2} \mathrm{NNH}_{2}\right)$ have all been used directly as fuels in APEMFC. Patents [149-150] introduced more fuels including hydrated hydrazine $\left(\mathrm{NH}_{2} \mathrm{NH}_{2} \cdot \mathrm{H}_{2} \mathrm{O}\right)$, hydrazine carbonate $\left(\left(\mathrm{NH}_{2} \mathrm{NH}_{2}\right)_{2} \mathrm{CO}_{2}\right)$, hydrazine sulfate $\left(\mathrm{NH}_{2} \mathrm{NH}_{2} \cdot \mathrm{H}_{2} \mathrm{SO}_{4}\right)$, monomethyl hydrazine $\left(\mathrm{CH}_{3} \mathrm{NHNH}_{2}\right)$, ammonia $\left(\mathrm{NH}_{3}\right)$, heterocycles such as imidazole and 1,3,5truazine and 3-amino-1,2,4-triazole, and hydroxylamines such as hydroxylamine $\left(\mathrm{NH}_{2} \mathrm{OH}\right)$ and hydroxylamine sulfate $\left(\mathrm{NH}_{2} \mathrm{OH} . \mathrm{H}_{2} \mathrm{SO}_{4}\right)$; the catalysts were Co-based for the fuel side (anode) and $\mathrm{Ag} / \mathrm{C}, \mathrm{Pt} / \mathrm{C}$ and Ni/C for the oxygen reduction side (cathode). EP 2133946 [151] disclosed the use of transition metals as catalysts in APEMFCs. There are numerous reports on the use of non-Pt catalyst, such as $\mathrm{MnO}_{2}$ [40], Ag/C [6, 96, 125], Au/C [125], FeTPP/BPC(Black Pearl Carbon) [152], CoPPyC [153], FeCo-CNF(Carbon Nanofiber) [154], CoFeN/C-HLH [155] in APEMFC cathodes and $\mathrm{Cr}-$ decorated Ni/C [6], Fe-Co-Ni/C [128, 156] at APEMFC anodes. A fully non-PGM-catalyst containing, metal-cation-free alkaline membrane fuel cell has been reported [6, 128]. For further reference, Spendelow and Wieckowski [157] have recently published a detailed review on electrocatalysis of oxygen reduction and small alcohol oxidation in alkaline media and detailed analyse of alkaline alcohol fuel cells can also be found in references [7, 158]; both these studies discuss the prospects for cheap APEMFCs. 
As mentioned above, recent intensive studies have led to the synthesis of AAEMs with high ion conductivities, reportedly comparable to Nafion ${ }^{\circledR}$. These promising AAEMs [93, 97-98, 103-104, 106, $116,135]$ are still to be evaluated in APEMFCs. The baseline properties of a selection of membrane candidates for APEMFC are summarized in Table 2. Most hydrocarbon AAEMs are soluble in various solvents, which is useful for the formulation of alkaline ionomers required for the preparation of high performance Membrane Electrode Assemblies (MEA). If the conductive properties reported can be translated into high power outputs, then APEMFC performances comparable to PEMFC can be expected in the near future.

Water is produced at anode and consumed at cathode in APEMFCs (when fuelled with hydrogen and with 4 electron reduction of oxygen at the cathode), which is fundamentally different to what occurs in PEMFCs containing acidic electrolytes; this can cause high overpotentials at APEMFC anodes, due to suspected flooding [159]. Alternative strategies for water management in developing APEMFC are therefore required. WO2009149195 [160] focuses on the water supply and suggests ways to operate APEMFC on a "water neutral" basis or with minimal supply of water from an external source. The APEMFC can also be run in dead-ended anode operation mode. The term "water neutral" means the cell or stack generates all of its water requirements internally (i.e. with no external supply of water). A wicking mesh was used to introduce liquid water, from either an external water source or internal water produced at the anode, to the cathode-side membrane surface. Partially hydrophilic anode back diffusion layers were used that were created from interweaving hydrophilic fibers with the wet-proofed carbon fibers so that the water produced at anode contacts the membrane directly and facilitates water back-diffusion from the anode to the cathode; this improved reactant mass transport in the anode because the electro-generated water was efficiently transported out of the anode structure. The patent reports peak power densities as high as $425 \mathrm{~mW} \mathrm{~cm} \mathrm{~cm}^{-2}$ when using non-Pt cathodes and 350 $\mathrm{mW} \mathrm{cm} \mathrm{cm}^{-2}$ for a wholly Pt-free fuel cell containing Tokuyama's anion exchange membrane.

Consider the anode and cathode reactions with acid and alkaline electrolytes: Water is clearly produced at the acid cathode equal quantities to the water consumed at alkaline cathode. This water can be used to maintain the water balance in fuel cells.

When using methanol and $\mathrm{O}_{2}$ as fuel and oxidant:

Using acid electrolyte 


$$
\text { Anode: } \mathrm{CH}_{3} \mathrm{OH}+\mathrm{H}_{2} \mathrm{O}-\mathrm{CO}_{2}+6 \mathrm{H}^{+}+6 \mathrm{e}^{-}
$$

Cathode: ${ }^{3} / 2 \mathrm{O}_{2}+6 \mathrm{H}^{+}+6 \mathrm{e}^{-}-3 \mathrm{H}_{2} \mathrm{O}$

Using alkaline electrolyte

$$
\begin{aligned}
& \text { Cathode: }{ }^{3} / 2 \mathrm{O}_{2}+3 \mathrm{H}_{2} \mathrm{O}+6 \mathrm{e}^{-}-6 \mathrm{OH}^{-} \\
& \text {Anode: } \mathrm{CH}_{3} \mathrm{OH}+6 \mathrm{OH}^{-}-\mathrm{CO}_{2}+5 \mathrm{H}_{2} \mathrm{O}+6 \mathrm{e}^{-}
\end{aligned}
$$

When using $\mathrm{H}_{2}$ and $\mathrm{O}_{2}$ as fuel and oxidant:

Using acid electrolyte

$$
\begin{aligned}
& \text { Anode: } 2 \mathrm{H}_{2}-4 \mathrm{H}^{+}+4 \mathrm{e}^{-} \\
& \text {Cathode: } \mathrm{O}_{2}+4 \mathrm{H}^{+}+4 \mathrm{e}^{-}-2 \mathrm{H}_{2} \mathrm{O}
\end{aligned}
$$

Using alkaline electrolyte

$$
\begin{aligned}
& \text { Cathode: } \mathrm{O}_{2}+2 \mathrm{H}_{2} \mathrm{O}+4 \mathrm{e}^{-}-4 \mathrm{OH}^{-} \\
& \text {Anode: } \mathrm{H}_{2}+4 \mathrm{OH}^{-}-2 \mathrm{H}_{2} \mathrm{O}+4 \mathrm{e}^{-}
\end{aligned}
$$

Simple arrangement of alkaline MEAs and acid MEAs would allow a more compact system that can operate without additional water supply. This is more important for direct methanol fuel cell systems as a higher concentration of methanol can be used (and this approach mitigates the severe cathode flooding that can happen in direct methanol fuel cells containing proton-exchange membranes). US20030049509 [161] and US20050069757 [162] discloses a method for combining the acid fuel cell (PEMFC) and alkaline fuel cell (APEMFC) together. One typical arrangement [162] is shown in Fig. (1).

US0235633 [163] extends this idea further. The cathode electrode was prepared using both alkaline and acidic ionomers, where the alkaline ionomer covered the catalyst and then this was carefully covered by acid ionomer. The water produced at the alkaline ionomer | acid ionomer interface would be utilized by the cathode catalyst; a key factor is the selection of solvent for both the alkaline ionomer and acid ionomer.

Based on the above concept, the water generated at the alkaline $\mid$ acid polymer electrolyte interfaces is ideal for maintenance of membrane hydration, and therefore ion conductivity, even when low (zero) humidity gases supplies are used; this has the potential to significantly simplify the fuel cell stack system. Recall that mass transport-derived performance losses are frequently caused when water is 
electro-generated in the electrode structures. This concept of hybrid membrane fuel cells [164-168], which contain both alkaline and acidic electrolyte membranes and electrolytes in the electrodes (a simple example is shown in Fig. (2)), was pioneered by Ünlü, Kohl and coworkers, and their results support the hypothesis that regardless of the configuration of the hybrid membrane fuel cell, the junction potentials at the AEM/PEM boundaries balance the $\mathrm{pH}$-induced shifts in the electrode standard potentials and maintain the thermodynamic cell voltage of $1.23 \mathrm{~V}$. Initial results show that acidic anodes and alkaline cathodes produce superior cell performances [164] and $116 \mathrm{~mW} \mathrm{~cm}{ }^{-2}$ was achieved at $80^{\circ} \mathrm{C}$ with dry $\mathrm{H}_{2}$ and $\mathrm{O}_{2}$ gas supplies [165]. Unlike the situation usually encountered with traditional PEMFCs or wholly alkaline APEMFCs, the hybrid (cationic-anionic as opposed to inorganic-organic) membranes cell performance decreases as the relative humidity of the gases are increased [164-165] and when under simple test conditions. This concept of zero water supply hybrid membrane fuel cells deserves further study; operation with alkaline cathodes and acidic anodes and membranes appears to be a particular promising combination.

\section{IMPORT ISSUES FOR ALKALINE MEMBRANE CONTAINING FUEL CELLS}

\subsection{Alkaline anion exchange ionomers for APEMFCs}

The importance of alkaline ionomers (anionomers) has been discussed in references [34, 36, 169]. Valade [170] synthesized ionomers by radical copolymerization of diallyldimethylammonium chloride (DADMAC) with chlorotrifluoroethylene (CTFE) or counter-ion exchange of a poly(DADMAC) containing fluorinated anions. The ion conductivities of these two ionomers were low (maximum of $0.79 \mathrm{mS} \mathrm{cm}{ }^{-1}$ ), however their use in fuel cells still led to a significant improvement on the cell performance. The University of Surrey developed its first generation ionomer (SION1) in 2006 [34], which was used to prepare MEAs yielding cell performance of $130 \mathrm{~mW} \mathrm{~cm}{ }^{-2}$ with an S80 membrane (Surrey's a radiation-grafted AAEM with $80 \pm 15 \mu \mathrm{m}$ thickness when hydrated) and $230 \mathrm{~mW} \mathrm{~cm} \mathrm{~cm}^{-2}$ with an S20 membrane $\left(20 \pm 10 \mu \mathrm{m}\right.$ hydrated thickness) at $50^{\circ} \mathrm{C}$ and where the $\mathrm{H}_{2}$ and $\mathrm{O}_{2}$ were supplied at ambient pressure. The synthesis of SION1 is shown in Scheme 3 [34]; this ionomer is nonideal in that it contains $\beta$-hydrogen atoms and requires deposition in organic solvents. However, it served its purpose and allowed for the evaluation of different AAEM in fuel cell tests (with peak power densities above the $1-2 \mathrm{~mW} \mathrm{~cm}{ }^{-2}$ achieved without the presence of ionomer). A second generation of ionomer is under development in our laboratory (published in a patent application [171]). The concept 
is that a water soluble anion exchange polymer is deposited on an electrodes and then rendered insoluble (e.g. by radiation and/or heat treatment). A major advantage is that no flammable organic solvents are required to prepare the MEAs: Organic solvents mixed with finely divided fuel cell catalysts would represent a significant hazard with mass MEA production.

In US5853798 [172] and WO09912659 [173], metal catalysts were deposited directly onto the surface of the membrane by soaking the membrane in a solution containing an anionic entity (a metal salt such as chloroplatinic acid, potassium tetrachloroplatinate etc.) with subsequent exposure to a reducing agent, such as sodium borohydride. This methodology guaranteed good ion conductivities in the catalyst layers without the use of an ionomer as the binder; it represents a simplified MEA architecture.

In EP1965456 [65], Tokuyama introduced an alkaline ionomer which used an intermediate layer containing a polyfunctional quaternizing agent which bonded the membrane and electrocatalyst layer together via cross-linking (selected examples presented in Table 3); examples 2-1 and 2-2 show excellent performance with peak power densities of $180 \mathrm{~mW} \mathrm{~cm}^{-2}$ at $0.6 \mathrm{~V}$. In another report, a commercially available membrane and an ionomer (designated I2) were used to prepare a MEA [57]; more than $400 \mathrm{~mW} \mathrm{~cm}^{-2}$ was achieved using a Pt/C catalyst while a respectable $200 \mathrm{~mW} \mathrm{~cm}^{-2}$ was obtained using a non-PGM catalyst (HYPERMEC ${ }^{\mathrm{TM}} 4020$ by Acta SpA) when using $\mathrm{H}_{2}$ as the fuel and a $\mathrm{CO}_{2}-$ free air supply at the cathode of the fuel cell.

Many researchers have reported that alkaline polymers with hydrocarbon backbones can be dissolved in solvents such as DMF, DMAc and DMSO [6, 96, 98, 103, 104, 105] and this allows their use as the ionomer for the preparation of MEAs. Zhuang et al. [1,6] used a quaternary ammonia polysulfone (QAPS) which can be dissolved in DMF and used as the ionomer; the QAPS polymer (in $\mathrm{OH}^{-}$form: $\left.\mathrm{IEC}=1.08 \mathrm{mmol} \mathrm{g}{ }^{-1}\right)$ was also used to fabricate the membrane, while the QAPS $\left(\mathrm{OH}^{-}\right.$form: IEC $=1.18 \mathrm{meq}^{-1}$ ) was used as the ionomer. The performance of the APEMFC was $110 \mathrm{~mW} \mathrm{~cm}^{-2}$ at $60^{\circ} \mathrm{C}\left(\mathrm{H}_{2} / \mathrm{O}_{2}\right)$. Gu and Yan et al. [174] developed an ionomer, tris(2,4,6-trimethoxyphenyl) polysulfone-methylene quaternary phosphonium hydroxide (TPQPOH: shown in Scheme 4), which is soluble in low boiling point and water soluble solvents such as methanol, ethanol, and $n$-propanol. The solubility of this kind of ionomer is ideal for use in APEMFC MEAs; $196 \mathrm{~mW} \mathrm{~cm} \mathrm{~cm}^{-2}$ was achieved at $80^{\circ} \mathrm{C}\left(\mathrm{H}_{2} / \mathrm{O}_{2}\right.$ gases supplied at $250 \mathrm{kPa}$ back-pressure $)$ using this phosphonium ionomer with a $70 \mu \mathrm{m}$ thick FAA commercial membrane (Fuma-Tech $\mathrm{GmbH}$ ) as the AAEM. This group has recently also 
used a quaternary phosphonium polyelectrolyte as the AAEM [101]; more than $250 \mathrm{~mW} \mathrm{~cm}^{-2}$ was obtained in a $\mathrm{H}_{2} / \mathrm{O}_{2}$ fuel cell at $50^{\circ} \mathrm{C}$ with a $50 \mu \mathrm{m}$ AAEM and gas back-pressures of $250 \mathrm{kPa}$. The presence of methoxy groups on the aromatic rings that are connected to the phosphonium ion centers is clearly essential for adequate chemical stability.

In state-of-the-art AAEM fuel cell technology, the role of the ionomer has not been fully investigated or understood; alkaline ionomer solutions/dispersions, comparable to the Nafion ${ }^{\circledR}$ dispersions used in PEMFCS (note: aqueous dispersions are available to allow mass production of MEAs containing finely divided catalysts), remains highly sought after. The development of alkaline ionomers is one of the major challenges for the development of high performance alkaline membrane containing fuel cells.

\subsection{Carbonate and bicarbonate containing anion exchange membranes}

In traditional aqueous $\mathrm{KOH}$ electrolyte containing Alkaline Fuel Cells (AFC), precipitation of the carbonate and/or bicarbonate salts can cause fuel cell performance losses or failures when air (containing carbon dioxide) is used as the oxidant [1]. The use of an AAEM as a solid electrolyte in the absence of metal cations prevents precipitation of carbonate/bicarbonate salts (the electrolyte containing the cationic groups is already a solid). However, research has now been conducted on carbonate and bicarbonate forms of AAEM; such carbonated alkaline anion exchange polymers have been utilized to capture $\mathrm{CO}_{2}$ as reported in US20100105126 [175]. The carbonation process is quick even if the AAEM has been exposed to the air for only a short time [5, 124]. The results presented in reference [135] confirm a quick decline of AAEM ionic conductivity as a function of air exposure time. These results imply that the conductivities of the AAEMs in $\mathrm{OH}^{-}$form may have been underestimated as most studies to date have not disclosed vigorous $\mathrm{CO}_{2}$ exclusion procedures during conductivity measurements. Indeed, it has been hypothezised that $\mathrm{OH}^{-}$ion conductivities in AAEMs can be estimated by measuring the ionic conductivities of $\mathrm{HCO}_{3}^{-}$form AAEMs and multiplying by 3.8 [135] . However, this carbonate process may not to be a serious problem due to the in situ "self-purging mechanism" as $\mathrm{OH}^{-}$anions are continuously generated at cathode of APEMFCs [3]. Park et al. report reasonable APEMFC performances $\left(30.1 \mathrm{~mW} \mathrm{~cm}^{-2}\right.$ with $\mathrm{Pt} / \mathrm{C}$ catalyst) when using air as the oxidant [96]. However, Piana et al. [57] reported a sharp drop of performance on a switch from $\mathrm{CO}_{2}-$ free air to 
atmospheric air. Although the performance of the fuel cell had deteriorated on the switch of oxidant supply, a subsequent durability test showed only a small drop in potential and power with time with operation with non-purified atmospheric air. Fuel cells operating with a "carbonate cycle" at low temperatures have also been demonstrated in [105, 176-177]. The presence of carbonate clearly does not affect the kinetics of the oxygen reduction reaction at the cathode $[176,178]$ and hydrogen oxidation was feasible in carbonate environments, where the reaction followed a 2-electron pathway, analogous to the reaction with hydroxide [178]. $\mathrm{CO}_{2}$ was also involved in the oxygen reduction reaction forming carbonate anions, which were transported from the cathode to the anode $[4,105,176$, 179]. Watanabe et al. studied the carbonate contents of MEAs during APEMFC operation and found that there was no change in $\mathrm{CO}_{3}{ }^{2-}$ ration in MEA over long time operation when using ambient air (contains $\mathrm{CO}_{2}$ ) for the oxidant, i.e. continuous accumulation of $\mathrm{CO}_{3}{ }^{2-}$ does not occur in APEMFC unlike in AFC [180]. Landon and Kitchin [181] found that oxygen and carbon dioxide gas mixtures can be selectively separated from air using an anion exchange membrane containing electrolytic cells with cell potentials below $1.23 \mathrm{~V}$ with transport of bicarbonate from the cathode to the anode through the anion exchange membrane. Oxygen (20\%) and carbon dioxide (1\%) in the air feed was concentrated to $85 \%$ and $15 \%$ in the product stream respectively. These results demonstrate the feasibility to operate the APEMFC using air as oxidant or with bicarbonate/carbonate cycles (when deliberately supplied with $\mathrm{CO}_{2} / \mathrm{O}_{2}$ (air) mixtures). The durability of the AAEM in carbonate solution improved over more strongly alkaline $\mathrm{OH}^{-}$solutions [88]. However, the true extent and mechanism of how $\mathrm{CO}_{2}$ affects the performance of APEMFC remains to be fully investigated. There are numerous hypotheses for the cause of the performance losses with the use of air at the cathode of APEMFCs: Are these performance losses due to (i) $\mathrm{pH}$ gradient (high at cathode, lower at anode) derived thermodynamic losses, (ii) reductions in ionic conductivity of the AAEM or alkaline ionomer, (iii) $\mathrm{CO}_{3}{ }^{2-} / \mathrm{HCO}_{3}{ }^{-}$anions interfering with the hydrogen oxidation electrode kinetics on the Pt catalyst at the anode (as mentioned above, the oxygen reduction reaction at the cathode appear less affected by the presence of these ions), and (iv) an effect on the water diffusion with the additional presence of nitrogen [176, 182-183]. Such investigations are an immediate research priority.

\section{CONCLUSIONS}


Alkaline anion-exchange membranes (AAEM) are the key material for Alkaline Polymer Electrolyte Membrane Fuel Cells (APEMFC) and are attracting significant worldwide interest; this is principally with the hope of reduced costs due to cheaper catalysts and system components (due to less corrosion issues with the use of alkaline solid electrolytes as opposed to acid conditions). Generally, AAEM synthesis is either from (i) direct polymerization (or copolymerization) of monomers where at least one of the monomers contains (cationic) anion exchange functional groups or (ii) where the anion exchange functional groups are introduced onto the polymer backbone via chlormethylization or sulphonation reactions with subsequent amination and/or quaternization. Sol-gel processes have also been used to introduce cross-links and enhance the AAEM stability (particularly with inorganicorganic hybrid membranes). The functional groups can also be introduced via irradiation grafting, typically using $\gamma$-rays and electron beams.

A large class of AAEMs are based on aromatic polymers, commonly involving polysulfones, polyetherketones and poly(phenylene oxide), and partial fluorinated, such as poly(ethylene-cotetrafluoroethylene), or fluorinated/perfluorinated polymers. Trimethylamine is commonly used as the quaternization agent. Increasing the number of functional groups in the polymer (without an increase in swelling or water uptake) and identifying active functional group with higher basicities will yield improved performances, AAEMs with remarkable ionic conductivities have been recently obtained.; ion conductivities as high as $75 \mathrm{mS} \mathrm{cm}{ }^{-1}$ at room temperature and $160 \mathrm{mS} \mathrm{cm}^{-1}$ at $90^{\circ} \mathrm{C}$ have been reported. However, ionic conductivities are more sensitive to humidity than proton-exchange membranes with rapid drops in conductivity at lower humidities. If the anion-exchange polymers can be dissolved in solvents (commonly polar solvents such as DMF, DMAc, and alcohols) they can be used for depositing ionomer solutions in the preparation of MEAs.

The promising results reported in this article suggest high performance APEMFCs will be realized in the near future. However, the anion-exchange polymer electrolyte chemical stabilities in alkaline environments have still to be adequately proven particularly in lower humidity environments (hydrated environments "protect" the anion exchange head-groups to a certain extent). The effect of carbonate and bicarbonate anions on the polymer electrolytes and on the resulting fuel cell performances remains to be fully resolved. 
An interesting development is that of fuel cells fabricated with hybrid electrolytes and membranes (containing mixed proton and alkali exchange groups): the ambition is the ability to operate fuel cells without external water supply (i.e. with $0 \%$ relative humidity, or ambient humidity, gas supplies). This promises significantly simplified fuel cell systems.

Finally, the authors suggest (for an idea of current research trends) perusal of the abstracts from the $218^{\text {th }}$ Electrochemical Society meetings in Las Vegas (Oct 2010), which contained many sessions on alkaline membrane fuel cell state-of-the-art.

\section{REFERENCES}

[1] Tang DP, Pan J, Lu SF, Zhuang L, Lu JT. Alkaline polymer electrolyte fuel cells: Principle, challenges, and recent progress. Sci China Chem 2010; 53: 357-64.

[2] Varcoe JR, Kizewski JP, Halepoto DM, Poynton SD,Slade RCT, Zhao F. In: Garche J, Dyer C, Moseley P, Ogumi Z, Rand D, Scrosati B, Eds “Anion-Exchange Membranes” in Encyclopedia of Electrochemical Power Sources. Amsterdam: Elsevier 2009: pp329-43.

[3] Adams LA, Poynton SD, Tamain C, Slade RCT, Varcoe JR. A carbon dioxide tolerant aqueouselectrolyte-free Anion-Exchange Membrane Alkaline Fuel Cell. ChemSusChem 2008; 1: 79-81.

[4] Unlu M, Zhou J, Kohl PA. Anion Exchange Membrane Fuel Cells: Experimental Comparison of Hydroxide and Carbonate Conductive Ions. Electrochem Solid-State Lett 2009; 12: B27-30.

[5] Yanagi H, Fukuta K. Anion Exchange Membrane and Ionomer for Alkaline Membrane Fuel Cells (AMFCs). Electrochem Soc Trans 2008; 16: 257-62.

[6] Lu SF, Pan J, Huang AB, Zhuang L, Lu JT. Alkaline polymer electrolyte fuel cells completely free from noble metal catalysts. Proc. Natl Acad Sci 2008 ; 105: 20611-4.

[7] Antolini E, Gonzalez ER. Alkaline direct alcohol fuel cells. J Power Sources 2010; 195: 3431-50.

[8] An L, Zhao TS, Shen SY, Wu QX, Chen R. Alkaline direct oxidation fuel cell with non-platinum catalysts capable of converting glucose to electricity at high power output. J Power Sources 2011; 196: $186-90$

[9] Asazawa K, Sakamoto T, Yamaguchi S, Yamada K, Fujikawa H, Tanaka H, Oguro K. Study of anode catalysts and fuel concentration on direct hydrazine alkaline anion-exchange membrane fuel cells. J Electrochem Soc 2009; 156: B509-12. 
[10] Lan R, Tao SW. Direct ammonia alkaline anion-exchange membrane fuel cells. Electrochem Solid State Lett 2010; 13: B83-6.

[11] Tao SW, Lan R, Irvine JTS. A direct urea fuel cell - power from fertiliser and waste. Energy Environ Sci 2010; 3: 438-41.

[12] Jamard R, Latour A, Salomon J, Capron P, Martinet-Beaumont A. Study of fuel efficiency in a direct borohydride fuel cell. J Power Sources 2008; 176: 287-92.

[13] Gellett W, Schumacher J, Kesmez M, Le D, Minteer SD. High Current Density Air-Breathing Laccase Biocathode. J Electrochem Soc 2010; 157: B557-62.

[14] Mo Y, Liang P, Huang X, Wang H, Cao X. Enhancing the stability of power generation of singlechamber microbial fuel cells using an anion exchange membrane. J Chem Technol Biotechnol 2009; 84: 1767-72.

[15] Kim JR,Cheng S, Oh S-E, Logan BE. Power Generation Using Different Cation, Anion, and Ultrafiltration Membranes in Microbial Fuel Cells. Environ Sci Technol 2007; 41: 1004-9.

[16] Tokuyama Soda Kabushiki Kaisha. Anion Exchange membranes and their production. GB1401997, 1972.

[17] Hansen RD, Wheaton RM. Seperation of acid from polymers by dialysis with anion exchange membrane. US3244620, 1966.

[18] Imoto R, Kosaka Y, Shimizu A. Process for manufacturing anion-exchange membranes from a graft copoloymer of SBR and a vinylpyridine reacted with an epoxy resin. US3258435, 1966.

[19] Hansen RD, Wheaton RM. Separation of acid by dialysis with anion-exchange membranes. US3272737, 1966.

[20] Süser A. Preparation of anion exchange membranes from cellulose sheets. US3714010, 1973.

[21] Scott, Rosedale, Moulton, Taylor, Gough. Anion exchange membranes. EP0382439, 1990.

[22] Altmeier P. Stark basische anionenaustauschermembranen und verfahren zu deren herstellung. W09506083, 1995.

[23] Altmeier, P. Strongly alkaline anion exchange membranes and process for producing the same. US5746917, 1998.

[24] Ehrikhovich KJ, Viktorovna SN, Aleksandrovich FJ, Semenovich GS, Mikhajlovich AJ, Vladimirovna SI, Alekseevna JN, Fedorovich TS. Method for production of anion-exchange membranes having high penetrability to chloride ion. RU2074204, 1997. 
[25] Jurevich TD. Method for modifying anion-exchange membranes MA-40. RU2303835, 2007.

[26] Aminabhavi T, Kulkarni PV, Kariduraganavar MY. Ion exchange membranes, methods and processes for production thereof and uses in specific applications. US7544278, 2009.

[27] Varcoe JR, Slade RCT. Prospects for Alkaline Anion-Exchange Membranes in Low Temperature Fuel Cells. Fuel Cells 2005; 5: 187-200.

[28] Danks TN, Slade RCT, Varcoe JR. Comparison of PVDF- and FEP-based radiation-grafted alkaline anion-exchange membranes for use in low temperature portable DMFCs. J Mater Chem 2002; 12: 3371-3.

[29] Danks TN, Slade RCT, Varcoe JR. Alkaline anion-exchange radiation-grafted membranes for possible electrochemical application in fuel cells. J Mater Chem 2003; 13: 712-21.

[30] Herman H, Slade RCT, Varcoe JR. The radiation-grafting of vinylbenzyl chloride onto poly(hexafluoropropylene-co-tetrafluoroethylene) films with subsequent conversion to alkaline anion-exchange membranes: optimisation of the experimental conditions and characterization. J Membrane Sci 2003; 218: 147-63.

[31] Tzanetakis N, Varcoe J, Slade RS, Scott K. Salt splitting with radiation grafted PVDF anionexchange membrane. Electrochem Comm 2003; 5: 115-9.

[32] Tzanetakis N, Varcoe JR, Slade RCT, Scott K. Radiation-grafted PVDF anion exchange membrane for salt splitting. Desalination 2005; 174: 257-65.

[33] Slade RCT, Varcoe JR. Investigations of conductivity in FEP-based radiation-grafted alkaline anion-exchange membranes. Solid State Ionics 2005; 176: 585-97.

[34] Varcoe JR, Slade RCT. An electron-beam-grafted ETFE alkaline anion-exchange membrane in metal-cation-free solid-state alkaline fuel cells. Electrochem Comm 2006; 8: 839-43.

[35] Varcoe JR, Slade RCT, Yee ELH, Poynton SD, Driscoll DJ, Apperley DC. Poly(ethylene-cotetrafluoroethylene)-Derived Radiation-Grafted Anion-Exchange Membrane with properties specifically tailored for application in Metal-Cation-Free Alkaline Polymer Electrolyte Fuel Cells. Chem Mater 2007; 19: 2686-93.

[36] Varcoe JR, Slade RCT, Yee ELH. An alkaline polymer electrochemical interface: a breakthrough in application of alkaline anion-exchange membranes in fuel cells. Chem Commun 2006; 1428-29.

[37] Shevchenko VV, Gumennaya MA, Synthesis and properties of anion-exchange membranes for fuel cells. Theoretical and Experimental Chemistry 2010; 46: 139-52. 
[38] Varcoe JR, Poynton SD, Slade RCT. In: Vielstich W, Gasteiger HA, Yokokawa H, Eds. Handbook of Fuel Cells - Fundamentals, Technology and Applications, Vol. 5: Advances in Electocatalysis, Materials, Diagnostics and Durability. John Wiley \& Sons 2009: 322-36.

[39] Hou HY, Sun GQ, He RH, Wu ZM, Sun BY. Alkali doped polybenzimidazole membrane for high performance alkaline direct ethanol fuel cell. J Power Sources 2008; 182: 95-9.

[40] Hou HY, Sun GQ, He RH, Sun BY, Jin W, Liu H, Xin Q. Alkali doped polybenzimidazole membrane for alkaline direct methanol fuel cell. Int J Hyd Energy 2008; 33: 7172-76.

[41] Modestov AD, Tarasevich MR, Leykin AY, Filimonov VY. MEA for alkaline direct ethanol fuel cell with alkali doped PBI membrane and non-platinum electrodes. J Power Sources 2009; 188: $502-6$.

[42] Xing B, Savadogo O. Hydrogen oxygen polymer electrolyte membrane fuel cells (PEMFCs) based on alkaline-doped polybenzimidazole (PBI). Electrochem Commun 2000; 2: 697-702.

[43] Savadogo O. Emerging membranes for electrochemical systems Part II. High temperature composite membranes for polymer electrolyte fuel cell (PEFC) applications. J. Power Sources 2004; 127: 135-61.

[44] Fu J, Qiao JL, Wang XZ, Ma JX, Okada T. Alkali doped poly(vinyl alcohol) for potential fuel cell applications. Synthetic Metals 2010; 160: 193-9.

[45] Yang CC, Lin CT, Chiu SJ. Preparation of the PVA/HAP composite polymer membrane for alkaline DMFC application. Desalination 2008; 233: 137-46.

[46] Yang CC, Chiu SJ, Chien WC, Chiu SS. Quaternized poly(vinyl alcohol)/alumina composite polymer membranes for alkaline direct methanol fuel cells. J Power Sources 2010; 195: 2212-9.

[47]Yang CC, Chiu SJ, Lee KT, Chien WC, Lin CT, Huang CA. Study of poly(vinyl alcohol)/titanium oxide composite polymer membranes and their application on alkaline direct alcohol fuel cell. $\mathbf{J}$ Power Sources 2008; 184: 44-51.

[48] Yang CC. Synthesis and characterization of the cross-linked PVA/TiO2 composite polymer membrane for alkaline DMFC. J Membrane Sci 2007; 288: 51-60.

[49] Wan Y, Peppley B, Creber KAM, Bui VT, Halliop E. Preliminary evaluation of an alkaline chitosan-based membrane fuel cell. J Power Sources 2006; 162: 105-13.

[50] Wan Y, Creber KAM., Peppley B, Bui VT. Chitosan-based electrolyte composite membranes II. Mechanical properties and ionic conductivity. J Membrane Sci 2006; 284: 331-8. 
[51] Wan Y, Creber KAM., Peppley B, Bui VT. Chitosan-based solid electrolyte composite membranes I. Preparation and characterization. J Membrane Sci 2006; 280: 666-74.

[52] Vassal N, Salmon E, Fauvarque JF. Electrochemical properties of an alkaline solid polymer electrolyte based on P(ECH-co-EO). Electrochim Acta 2000; 45: 1527-32.

[53] Yang CC, Chiu SJ, Chien WC. Development of alkaline direct methanol fuel cells based on crosslinked PVA polymer membranes. J Power Sources 2006; 162: 21-9.

[54] Fauvarque JF. Alkaline solid polymer electrolyte, electrode and electrochemical generator containing such as electrolyte. US5569559, 1996.

[55] Parent CR, Boulton JM, Fooksa R. Alkaline Cell with polymer electrolyte. US20040023110, 2004.

[56] Matsuoka K, Chiba S, Iriyama Y, Abe T, Matsuoka M, Kikuchi K, Ogumi Z. Preparation of anion-exchange membrane by plasma polymerization and its use in alkaline fuel cells. Thin Solid Films 2008; 516: 3309-13.

[57] Piana M, Boccia M, Filpi A, Flammia E, Miller HA, Orsini M, Salusti F, Santiccioloi S, Ciardelli F, Pucci A. H2/air alkaline membrane fuel cell performance and durability, using novel ionomer and non-platinum group metal cathode catalyst. J Power Sources 2010; 195: 5875-81.

[58] Yanagi H, Fukuta K. Anion Exchange Membrane and Ionomer for Alkaline Membrane Fuel Cells (AMFCs). ECS Trans 2008; 16: 257-62.

[59] Li YS, Zhao TS, Liang ZX. Performance of alkaline electrolyte-membrane-based direct ethanol fuel cells. J Power Sources 2009; 187: 387-92.

[60] Kim JH, Kim HK, Hwang KT, Lee JY. Performance of air-breathing direct methanol fuel cell with anion-exchange membrane. Int J Hyd Eng 2010; 35: 768-73.

[61] Matsuoka K, Iriyama Y, Abe T, Matsuoka M, Ogumi Z. Alkaline direct alcohol fuel cells using an anion exchange membrane. J Power Sources 2005; 150: 27-31.

[62] Li YS, Zhao TS, Liang ZX. Effect of polymer binders in anode catalyst layer on performance of alkaline direct ethanol fuel cells. J Power Sources 2009; 190: 223-9.

[63] Fujiwara N, Siroma Z, Yamazaki SI, Ioroi T, Senoh H, Yasuda K. Direct ethanol fuel cells using an anion exchange membrane. J Power Sources 2008; 185: 621-6.

[64] Bunazawa H, Yamazaki Y. Influence of anion ionomer content and silver cathode catalyst on the performance of alkaline membrane electrode assemblies (MEAs) for direct methanol fuel cells (DMFCs). J Power Sources 2008; 182: 48-51. 
[65] Matsuoka H, Fukuta K. Electrolyte membrane-electrode membrane assembly for solid polymer fuel cell, process for producing the electrolyte membrane-electrode membrane assembly, and fuel cell comprising the electrolyte membrane-electrode membrane assembly. EP1965456, 2008.

[66] Matsuoka H, Fukuta K. Quaterinizing agent for anion exchange resin film formation, gas diffusion electrode film, solid electrolyte membrane, and solid polymer fuel cell equipped with same. JP2007188788, 2007.

[67] Fukuta K, Isomura T, Yanagi H. Solid polymer electrolyte fuel cell membrane. WO2009081812, 2009.

[68] Isomura T, Fukuta K, Yanagi H. Diaphragm for fuel cell and process for producing the same. WO2009096473, 2009.

[69] Isomura T, Fukuta K, Yanagi H. Diaphragm for direct liquid fuel cell and method for producing the same. WO2009081931, 2009.

[70] Fukuta K, Watanabe S, Mashita Y, Yanagi H. Method for producing ion conductivity-imparting agent for catalyst electrode layer of anion-exchange membrane fuel cell. WO2009148051, 2009.

[71] Fukuta K, Watanabe S, Yanagi H. Method for producing anion exchange membrane for solid polymer electrolyte-type fuel cell. WO2010041641, 2010.

[72] Matsuoka H, Fukuta K, Sakata K. Diaphragm for direct liquid fuel cell and method for producing the same. US20100104920, 2010.

[73] Hibbs MR, Fujimoto CH, Cornelius CJ. Synthesis and Characterization of Poly(phenylene)-Based Anion Exchange Membranes for Alkaline Fuel Cells. Macromolecules 2009; 42: 8316-21.

[74] Fang J, Shen PK. Quaternized poly(phthalazinon ether sulfone ketone) membrane for anion exchange membrane fuel cells. J Membr Sci 2006; 285: 317-22.

[75] Zeng QH, Liu QL, Broadwell I, Zhu AM, Xiong Y, Tu XP. Anion exchange membranes based on quaternized polystyrene-block-poly(ethylene-ran-butylene)-block-polystyrene for direct methanol alkaline fuel cells. J Membrane Sci 2010; 349: 237-43.

[76] Hibbs MR, Hickner MA, Alam TM, McIntyre SK, Fujimoto CH, Cornelius CJ. Transport Properties of Hydroxide and Proton Conducting Membranes. Chem Mater 2008; 20: 2566-73.

[77] Wang GG, Weng YM, Zhao J, Chen RR, Xie D. Preparation of a functional Poly(ether imide) Membrane for potential Alkaline Fuel Cell applications: Chloromethylation. J Appl Polym Sci 2009; 112: 721-7. 
[78] Wang GG, Weng YM, Chu D, Xie D, Chen RR. Preparation of alkaline anion exchange membranes based on functional poly(ether-imide) polymers for potential fuel cell applications. $\mathbf{J}$ Membrane Sci 2009; 326: 4-8.

[79] Xie D, Chen RR, Wang GG, Hsu A. Anion exchange membranes. WO2009089355, 2009.

[80] EI Moussaoui R, Martin R. Solid alkaline fuel cell comprising ion exchange membrane. EP1612874, 2004

[81] EI Moussaoui R, Martin R. Solid alkaline fuel cell comprising ion exchange membrane. WO2006003182, 2006

[82] Kong XQ, Wadhwa K, Verkade JG, Schmidt-Rohr K. Determination of the structure of a novel Anion Exchange Fuel Cell Membrane by Solid-State Nuclear Magnetic Resonance Spectroscopy, Macromolecules 2009; 42: 1659-64.

[83] Scott GWR, Taylor TMC, Gough P. Anion exchange membrane. EP0382439, 1990.

[84] Macomber CS, Boncella JM, Pivovar BS, Rau JA. Decomposition pathways of an alkaline fuel cell membrane material component via evolved gas analysis. J Therm Anal Calor 2008; 93: 225-9.

[85] Chempath S, Boncella JM, Pratt LR, Henson N, Pivovar BS. Density functional theory study of degradation of tetraalkylammonium hydroxides. J Phys Chem C 2010; 114: 11977-83.

[86] Huang AB, Xia CY, Xiao CB, Zhuang L. Composite Anion Exchange Membrane for Alkaline Direct Methanol Fuel Cell: Structural And Electrochemical Characterization. J Appl Polym Sci 2006; 100: 2248-51.

[87] Sata T, Tsujimoto M, Yamaguchi T, Matsusaki K. Change of anion exchange membranes in an aqueous sodium hydroxide solution at high temperature. J Membr Sci 1996; 112: 161-70.

[88] Vega JA, Chartier C, Mustain WE. Effect of hydroxide and carbonate alkaline media on anion exchange membranes. J Power Sources 2010; 195: 7176-80.

[89] Sollogoub C, Guinault A, Bonnebat C, Bennjima M, Akrour L, Fauvarque JF, Ogier L. Formation and characterization of cross-linked membranes for alkaline fuel cells. J Membrane Sci 2009; 335: $37-42$.

[90] Komkova EN, Stamatialis DF, Strathmann H, Wessling M. Anion-exchange membranes containing diamines: preparation and stability in alkaline solution. J Membr Sci 2004; 244: 25-34.

[91] Tomoi M, Yamaguchi K, Ando R, Kantake Y, Aosaki Y, Kubota H. Synthesis and thermal stability of novel anion exchange resins with spacer chains. J Appl Polym Sci 1997; 64: 1161-7. 
[92] Marx D, Chandra A, Tuckerman ME. Aqueous Basic Solutions: Hydroxide Solvation, Structural Diffusion, and Comparison to the Hydrated Proton. Chem Rev 2010; 110: 2174-216.

[93] Robertson NJ, Kostalik IV HA, Clark TJ, Mutolo PF, Abruna HD, Coates GW. Tunable high performance cross-linked Alkaline Anion Exchange Membranes for Fuel Cell applications. J Am Chem Soc 2010; 132: 3400-4.

[94] Hickner MA. Mechanisms of morphology development and water motion in Proton Exchange Membranes. ECS Tran 2010; 33: 51-5.

[95] Mulford AE. Copolymers based on propylene and styrene, process for the preparation thereof and anion-exchange membranes made therefrom. IL 33094, 1973.

[96] Park JS, Park SH, Yim SD, Yoon YG, Lee WY, Kim CS. Performance of solid alkaline fuel cells employing anion-exchange membranes. J Power Sources 2008; 178: 620-6.

[97] Tanaka M, Koike M, Miyatake K, Watanabe M. Anion conductive aromatic ionomers containing fluorenyl groups. Macromolecules 2010; 43: 2657-9.

[98] Wang JH, Li SH, Zhang SB. Novel Hydroxide-Conducting Polyelectrolyte composed of an Poly(arylene ether sulfone) containing pendant Quaternary Guanidinium groups for Alkaline Fuel Cell applications. Macromolecules 2010; 43: 3890-6.

[99] Zhang Q, Li SH, Zhang SB. A novel guanidinium grafted poly(aryl ether sulfone) for highperformance hydroxide exchange membrane. Chem Commun 2010; 46: 7495-7.

[100] Kim DS, Kim YS. Anion conducting polyaromatics having guanidine base. ECS Trans 2010; 33: $1867-74$.

[101] Gu S, Cai R, Luo T, Jensen K, Contreras C, Yan Y. Quaternary Phosphonium-Based Polymers as Hydroxide Exchange Membranes. Chem Sus Chem 2010; 3: 555-8.

[102] Arges C, Kulkarni S, Baranek A, Pan K-J, Jung M-S, Patton D, Mauritz KA, Ramani V. Quaternary ammonium and phosphonium based anion exchange membrane for Alkaline Fuel Cells. ECS Trans 2010; 33: 1903-13.

[103] Guo ML, Fang J, Xu HK, Li W, Lu XH, Lan CH, Li KY. Synthesis and characterization of novel anion exchange membranes based on imidazolium-type ionic liquid for alkaline fuel cells. $\mathbf{J}$ Membr Sci 2010; 362: 97-104. 
[104] Wang JH, Zhao Z, Gong FX, Li SH, Zhang SB. Synthesis of soluble Poly(arylene ether sulfone) ionomers with pendant Quaternary Ammonium groups for Anion Exchange Membranes. Macromolecules 2009; 42: 8711-7.

[105] Zhou J, Unlu M, Vega J, Kohl P. Anionic polysulfone ionomers and membranes containing fluorenyl groups for anionic fuel cells. J Power Sources 2009; 190: 285-92.

[106] Tripathi BP, Kumar M, Shahi VK. Organic-inorganic hybrid alkaline membranes by epoxide ring opening for direct methanol fuel cell applications. J Membr Sci 2010; 360: 90-101.

[107] Wu YH, Wu CM, Xu TW, Lin XC, Fu YX. Novel silica/poly(2,6-dimethyl-1,4-phenylene oxide) hybrid anion-exchange membranes for alkaline fuel cells: Effect of heat treatment. J Membr Sci 2009; 338: 51-60.

[108] Wu YH, Wu CM, Varcoe JR, Poynton SD, Xu TW, Fu YX. Novel silica/poly(2,6-dimethyl-1,4phenylene oxide) hybrid anion-exchange membranes for alkaline fuel cells: Effect of silica content and the single cell Performance. J Power Sources 2010; 195: 3069-76.

[109] Zhang SL, Xu TW, Wu CM. Synthesis and characterizations of novel, positively charged hybrid membranes from poly(2,6-dimethyl-1,4-phenylene oxide). J Membr Sci 2006; 269: 142-51.

[110] Wu CM, Wu YH, Xu TW, Fu YX. Novel Anion-Exchange Organic-Inorganic Hybrid membranes prepared through Sol-Gel reaction and UV/thermal curing. J Appl Polym Sci, 2008; 107: $1865-71$.

[111] Wu YH, Wu CM, Yu F, Xu TW, Fu YX. Free-standing anion-exchange PEO-SiO ${ }_{2}$ hybrid membranes. J Membr Sci 2008; 307: 28-36.

[112] Wu YH, Wu CM, Xu TW, Yu F, Fu YX. Novel anion-exchange organic-inorganic hybrid membranes: Preparation and characterizations for potential use in fuel cells. J Membr Sci 2008; 321: 299-308.

[113] Xiong Y, Fang J, Zeng QH, Liu QL. Preparation and characterization of cross-linked quaternized poly(vinyl alcohol) membranes for anion exchange membrane fuel cells. J Membr Sci 2008; 311: $319-25$.

[114] Xiong Y, Liu QL, Zhu AM, Huang SM, Zeng QH. Performance of organic-inorganic hybrid anion-exchange membranes for alkaline direct methanol fuel cells. J Power Sources 2009; 186: $328-33$. 
[115] Suzuki S, Nagai M. Silicone based alkaline electrolyte membrane for fuel cell. Mater Sci Eng B $2009 ; 161: 138-41$.

[116] Clark TJ, Robertson NJ, Kostalik IV HA, Lobkovsky EB, Mutolo PF, Abruna HD, Coates GW. A ring-opening metathesis polymerization route to Alkaline Anion Exchange Membranes: Development of hydroxide-conducting thin films from an Ammonium-Functionalized monomer. $\mathbf{J}$ Am Chem Soc 2009; 131: 12888-9.

[117] Kostalik IV HA, Clark TJ, Robertson NJ, Mutolo PF, Longo JM, Abruna HD, Coates GW. Solvent processable tetraalkylammonium-functionlized polyethylene for use as an Alkaline Anion Exchange Membrane. Macromolecules 2010; 43: 7147-50.

[118] Nasef MM, Hegazy EA. Preparation and applications of ion exchange membranes by radiationinduced graft copolymerization of polar monomers onto non-polar films. Prog Polym Sci 2004; 29: 499-561.

[119] Stone C, Steck AE. Graft polymeric membranes and ion-exchange membranes formed therefrom. US6359019, 2002.

[120] Stone C, Steck AE. Graft polymeric membranes and ion-exchange membranes formed therefrom. WO0158576, 2001.

[121] Browning DJ, Lovell KV, Horsfall JA, Waring SC. Anion exchange membranes. WO 2008090351,2008

[122] Browning DJ, Lovell KV, Horsfall JA, Waring SC. Anion exchange membranes. US20100062313, 2010.

[123] Larsen MJ, Ma Y, Qian H, Toftlund H, Lund PB, Skou EM. Stability of radicals in electronirradiated fluoropolymer film for the preparation of graft copolymer fuel cell electrolyte membranes. Solid State Ionics 2010; 181: 201-5.

[124] Kizewski JP, Mudri NH, Zeng R, Poynton SD, Slade RCT, Varcoe JR. Alkaline Electrolytes and Reference Electrodes for Alkaline Polymer Electrolyte Membrane Fuel cells. ECS Trans 2010; 33: $27-35$

[125] Poynton SD, Kizewski JP, Slade RCT, Varcoe JR. Novel electrolyte membranes and non-Pt catalysts for low temperature fuel cells. Solid State Ionics 2010; 181: 219-22.

[126] Watanabe H, Takahashi H, Takeguchi T, Yamanaka T, Ueda W. Performance of Solid Alkaline Fuel Cells employing Layered Perovskite-Type Oxides as electrolyte. ECS Trans 2010; 33: 1825-9. 
[127] Matsuda M, Murota T, Takahashi H, Takeguchi T, Ueda W. Development of novel NaCo2O4 film electrolyte for Alkaline Fuel Cells. ECS Trans 2010; 33: 1831-6.

[128] Takeguchi T, Takahashi H, Yamanaka T, Nakamura A, Ueda W. Development of direct-ethanol anion-conducting solid alkaline inorganic Fuel Cell. ECS Trans 2010; 33: 1847-51.

[129] Takahashi H, Takeguchi T, Yamanaka T, Kyomen T, Ueda W. Ion conduction in layered oxide solid electrolyte. ECS Trans 2010; 33: 1861-1866.

[130] Pivovar BS, Thorn DL. Anion-conducting polymer, composition, and membrane. US7439275, 2008.

[131] Pivovar BS, Thorn DL. Anion-conducting polymer, composition, and membrane. US 7582683, 2009.

[132] Gaertner R, Herz HG, Maier G. Polymers based on polydiallyl ammonium compounds, anion exchange membranes containing the polymers, and the use thereof in fuel cells. WO2009083509, 2009.

[133] Zhang HW, Zhou ZT. Alkaline Polymer Electrolyte Membranes from Quaternized Poly(phthalazinone ether ketone) for Direct Methanol Fuel Cell. J Appl Poly Sci 2008; 110: 175662.

[134] Pan J, Lu SF, Li Y, Huang AB, Zhuang L, Lu JT. High-Performance Alkaline Polymer Electrolyte for Fuel Cell applications. Adv Funct Mater 2010; 20: 312-9.

[135] Yan JL, Hickner MA. Anion Exchange Membranes by Bromination of BenzylmethylContaining Poly(sulfone)s. Macromolecules 2010; 43: 2349-56.

[136] Li L, Wang YX. Quaternized polyethersulfone Cardo anion exchange membranes for direct methanol alkaline fuel cells. J Membrane Sci 2005; 262: 1-4.

[137] Altmeier P. Strongly alkaline anion exchange membranes and process for producing the same. US5746917, 1998.

[138] Altmeier P. Stark basische anionenaustauschermembranen und verfahren zu deren herstellung. WO9506083, 1995.

[139] Wan Y, Peppley B, Creber KAM, Bui VT. Anion-exchange membranes composed of quaternized-chitosan derivatives for alkaline fuel cells. J Power Sources 2010; 195: 3785-93.

[140] Mulford AE. Copolymers of vinyl alcohol and nitrogen-containing vinyl monomers, process for the preparation thereof and anion exchange membranes composed thereof. IL 33075, 1973. 
[141] Wan Y, Peppley B, Creber KAM, Bui VT, Halliop E. Quaternized-chitosan membranes for possible applications in alkaline fuel cells. J Power Sources 2008; 185: 183-7.

[142] Kumar M, Singh S, Shahi VK. Cross-Linked Poly(vinyl alcohol)-Poly(acrylonitrile-co-2dimethylamino ethylmethacrylate) Based Anion-Exchange Membranes in aqueous media. J Phy Chem B 2010; 114: 198-206.

[143] Yao W, Tsai T, Chang YM, Chen M. Polymer-based hydroxide conducting membranes. US6183914, 2001.

[144] Hodgdon RB, MacDonald RJ, Alexander SS. High ion exchange capacity polyelectrolytes having high crosslink densities and caustic stability. US5118717, 1992.

[145] Hodgdon RB, MacDonald RJ, Alexander SS. High ion exchange capacity polyelectrolytes having high crosslink densities and caustic stability. US 5284879, 1994.

[146] Hong JH, Li D, Wang HT, Weak-base anion exchange membranes by amination of chlorinated polypropylene with polyethyleneimine at low temperatures. J Membr Sci 2008; 318: 441-4.

[147] Aminabhavi T, Kulkarni PV, Kariduraganavar MY. Ion exchange membranes, methods and processes for production thereof and uses in specific applications. US7544278, 2009.

[148] MacDonald RJ. Sythesis of water soluble cross-linkers and their use in the manufacture of anionic polymers. US4374720, 1983.

[149] Asazawa, Yamada, Tanaka. Fuel cell. EP 1843416, 2007.

[150] Tanaka, Yamada, Asazawa. Fuel cell. EP1460705, 2004.

[151] Asazawa, Yamada, Tanaka. Fuel cell. EP 2133946, 2009.

[152] Ramaswamy N, Mukerjee S. Electrocatalysis of oxygen reduction on non-precious metallic centers at high pH environments. ECS Trans 2010; 33: 1777-85.

[153] Asazawa K, Yamamoto K, Yamada K, Tanaka H, Matsumura D, Tamura K, Nishihata Y, Atanassov P. XAFS analysis of unpyrolyzed CoPPyC oxygen reduction catalyst for AnionExchange Membrane Fuel Cells (AMFC). ECS Trans 2010; 33: 1751-5.

[154] Jeong B, Uhm S, Lee J. Iron-cobalt modified electrospun carbon nanofibers as oxygen reduction catalysts in Alkaline Fuel Cells. ECS Trans 2010; 33: 1757-67.

[155] Li XG, Popov BN, Kawahara T, Yanagi H. Recent advances in Non-Precious Metal catalysts for oxygen reduction reaction in Fuel Cells. ECS Trans 2010; 33: 1769-76. 
[156] Nakamura A, Takahashi H, Takeguchi T, Yamanaka T, Wang Q, Uchimoto Y, Ueda W. Effect of reduction temperature of $\mathrm{Fe}-\mathrm{Co}-\mathrm{Ni} / \mathrm{C}$ catalyst on the Solid Alkaline Fue Cell performance. ECS Trans 2010; 33: 1817-21.

[157] Spendelow JS, Wieckowski A. Electrocatalysis of oxygen reduction and small alcohol oxidation in alkaline media. Phys Chem Chem Phys 2007; 9: 2654-75.

[158] Yu EH, Krewer U, Scott K. Principles and materials aspects of Direct Alkaline Alcohol Fuel Cells. Energies 2010; 3: 1499-528.

[159] Zeng R, Poynton SD, Kizewski JP, Slade RCT, Varcoe JR. A novel reference electrode for application in alkaline polymer electrolyte membrane fuel cells. Electrochem Comm 2010; 12 : 823-5.

[160] Gottesfeld S, Dekel D, Gottesfeld Z, Simakov DS. Alkaline membrane fuel cells and apparatus and methods for supplying water thereto. WO2009149195, 2009

[161] Divisek J. Alkaline direct methanol fuel cell. US20030049509, 2003.

[162] Manfred S, Muller J. Fuel cell combination. US20050069757, 2005.

[163] Jaouen F. A cathode layer structure for a solid polymer fuel cell and fuel cell incorporating such structure. WO0235633, 2002

[164] Ünlü M, Zhou JF, Kohl PA. Hybrid anion and proton exchange membrane Fuel Cells. J Phys Chem C 2009; 113: 11416-23.

[165] Ünlü M, Zhou J, Kohl PA. Self humidifying hybrid Anion-Cation membrane Fuel Cell operated under dry conditions. Fuel Cells 2010; 10: 54-63.

[166] Ünlü M, Zhou J, Kohl PA. Hybrid Polymer Electrolyte Fuel Cells: Alkaline Electrodes with Proton Conducting Membrane. Angew Chem Intl Ed 2010; 49: 1299-301.

[167] Ünlü M, Zhou J, Kohl PA. Study of Alkaline Electrodes for Hybrid Polymer Electrolyte Fuel Cells. J Electrochem Soc 2010; 157: B1391-6.

[168] Unlu M, Kohl P, Zhou JF. Hybrid ionomer electrochemical devices. US20100028736, 2010

[169] Agel E, Bouet J, Fauvarque JF. Charaterization and use of anionic membranes for alkaline fuel cells. J Power Sources 2001; 101: 267-74.

[170] Valade D, Boschet F, Roualdes S, Ameduri B. Preparation of Solid Alkaline Fuel Cell binders based on fluorinated poly(diallyldimethylammonium chloride)s [Poly(DADMAC)] or 
poly(chlorotrifluoroethylene-co-DADMAC) copolymers. J Polym Sci A: Polym Chem 2009; 47: 2043-58.

[171] Varcoe JR, Poynton S, Slade R, Handsel J. Interface polymer. WO2010018370, 2010.

[172] Dube JR. Process for formation of an electrode on an anion exchange membrane. US5853798, 1998.

[173] Dube JR. Process for formation of an electrode of an anion exchange membrane. WO09912659, 1999.

[174] Gu S, Cai R, Luo T, Chen ZW, Sun MW, Liu Y, He GH, Yan YS. A soluble and highly conductive ionomer for high-performance Hydroxide Exchange Membrane Fuel Cells. Angew Chem Int Ed 2009; 48: 6499 -502.

[175] Wright AB, Lackner KS, Ginster U. Method and apparatus for extracting carbon dioxide from air. US20100105126, 2010.

[176] Vega J, Mustain W. Effect of $\mathrm{CO}_{2}, \mathrm{HCO}_{3}{ }^{-}$and $\mathrm{CO}_{3}{ }^{2-}$ on oxygen reduction in anion exchange membrane fuel cells. Electrochim Acta 2010; 55: 1638-44.

[177] Lang C, Kim K, Kohl P. High-Energy Density, Room-Temperature Carbonate Fuel Cell. Electrochem Solid State 2006; 9: A545-8.

[178] Vega JA, Chartier C, Smith S, Mustain WE. Effect of Carbonate on Oxygen Reduction, Hydrogen Oxidation and Anion Exchange Membrane Chemical Stability. ECS Trans 2010; 33: 1735-49.

[179] Inoue $\mathrm{H}$, Watanabe $\mathrm{S}$, Yanagi $\mathrm{H}$. In-situ Observation of $\mathrm{CO}_{2}$ through the Self-purging in Alkaline Membrane Fuel Cell (AMFC). ECS Trans 2009; 19: 23-7.

[180] Watanabe S, Fukuta K, Yanagi H. Determination of carbonate ion in MEA during the Alkaline Membrane Fuel Cell (AMFC) operation. ECS Trans 2010; 33: 1837-45.

[181] Landon J, Kitchin J. Electrochemical concentration of $\mathrm{O}_{2}$ and $\mathrm{CO}_{2}$ from the air using an anion exchange membrane. 215th ECS Meeting., San Francisco, Canada May 2009.

[182] Wang Y, Li L, Hu L, Zhuang L, Lu J, Xu B. A feasibility analysis for alkaline membrane direct methanol fuel cell: thermodynamic disadvantages versus kinetic advantages. Electrochem Commun 2003; $5: 662-6$.

[183] Matsui Y, Saito M, Tasaka A, Inaba M. Influence of Carbon Dioxide on the Performance of Anion-Exchange Membrane Fuel Cells. Electrochem Soc Trans 2010; 25: 105-10. 
Scheme 1 The formation of AAEMs from Polysulfones via direct chloromethylation [79].

Scheme 2 The synthesis of radiation-grafted ETFE-based AAEM [34].

Scheme 3 The synthesis of SION alkaline polymer electrochemical interface (alkaline ionomer) [34].

Scheme 4 The chemical structure of the quaternary phosphonium alkaline ionomer [174].

Fig. (1) A diagram of an acid-alkaline fuel cell combination [162]

Fig. (2) A simple hybrid-membrane fuel cell configuration. 


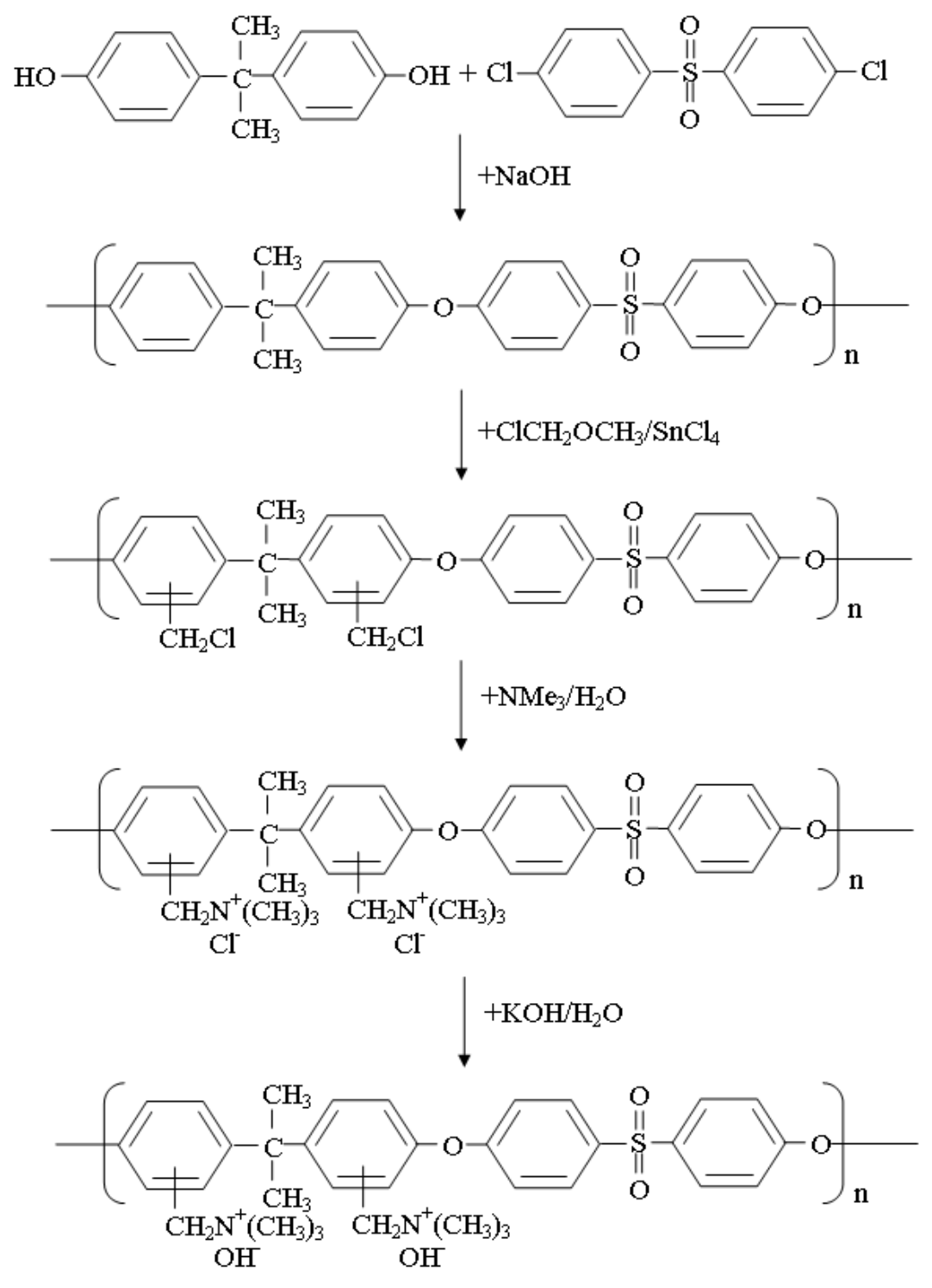

Scheme 1 


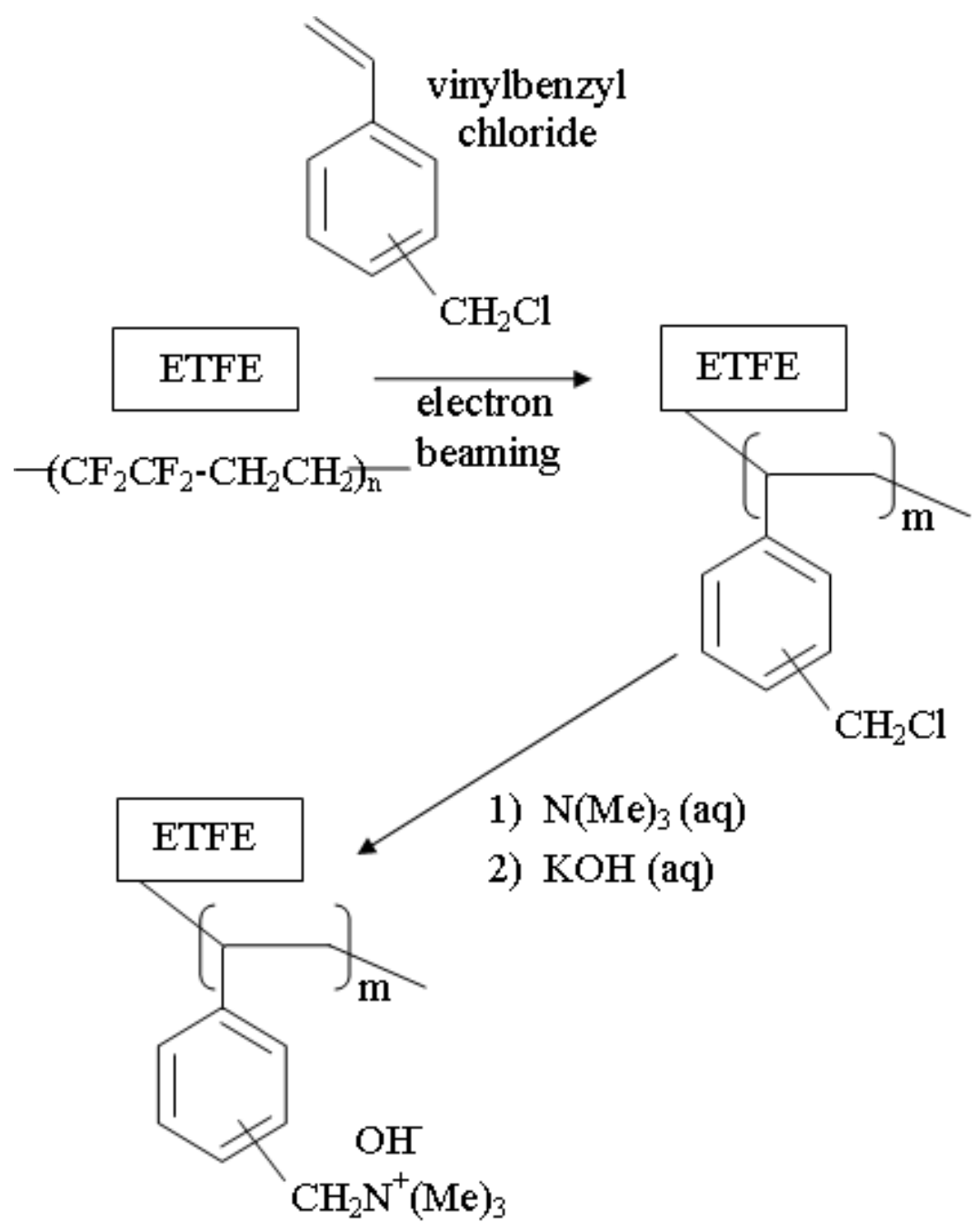

Scheme 2 


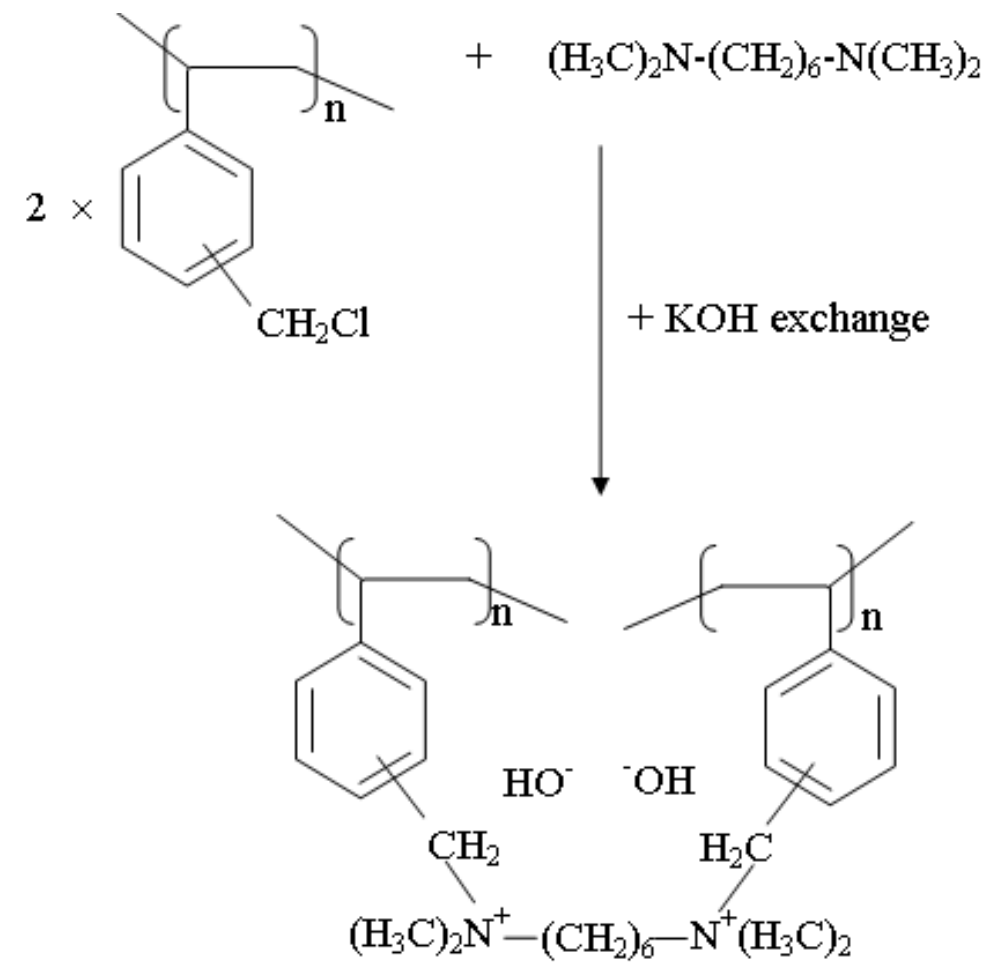

Scheme 3 

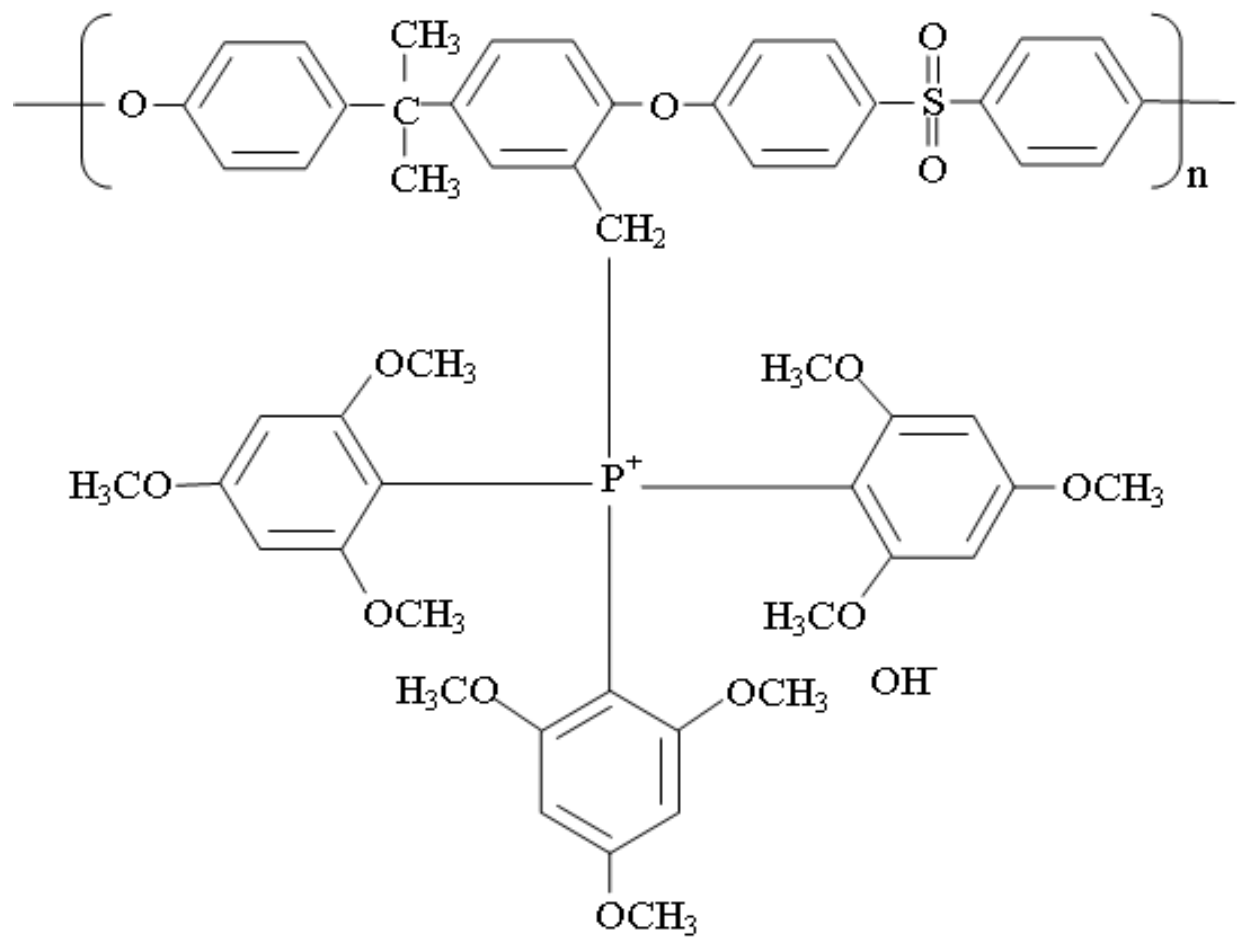

Scheme 4 
$\mathrm{H}_{2}$ or methanol $\mathrm{H}_{2}$ or methanol

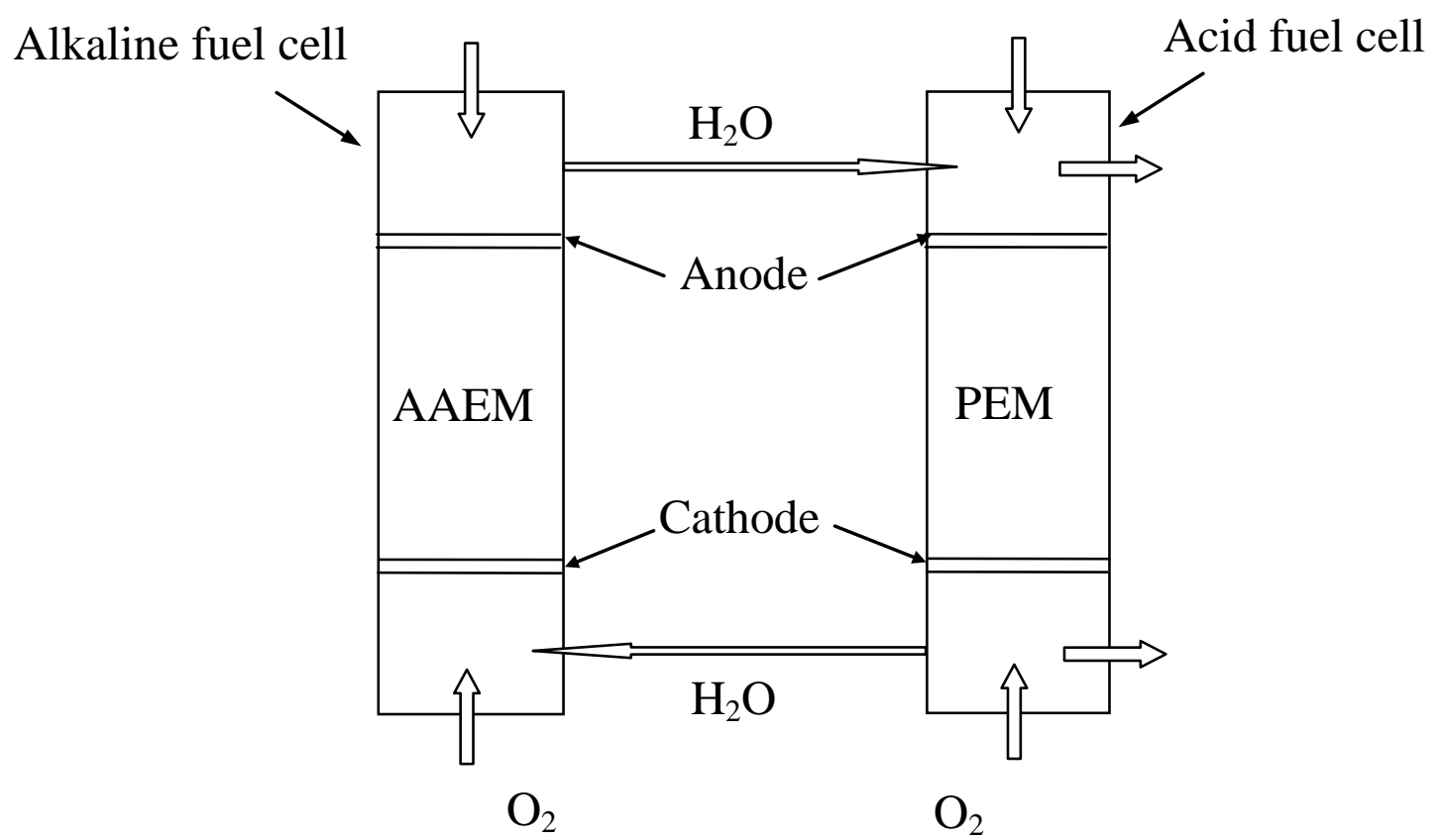

Fig. (1) 


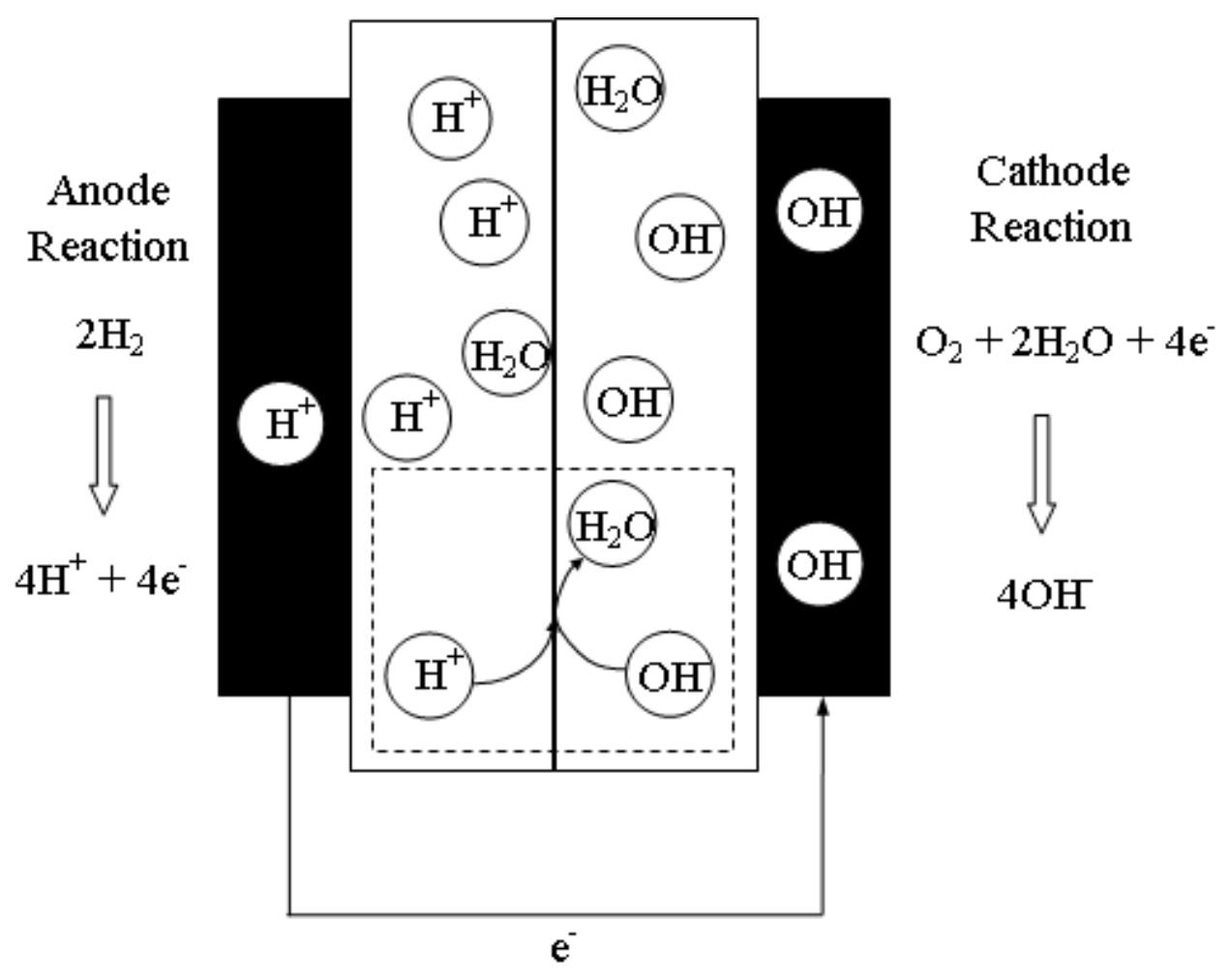

Fig. (2) 
Table 1 Summary of AAEM chemistry and preparation methodologies

\begin{tabular}{|c|c|c|c|}
\hline Polymer Class or Base & Key Chemistry & $\begin{array}{l}\text { Summary of Preparation Methodology (where applicable) } \\
\end{array}$ & References \\
\hline $\begin{array}{l}\text { Fluorinated, partially fluorinated and non- } \\
\text { fluorinated base polymer such as FEP, ETFE, and } \\
\text { LDPE }\end{array}$ & $\begin{array}{l}\text { Active functional groups: } \\
\text { benzyl- }-\mathrm{N}\left(\mathrm{CH}_{3}\right)_{3}{ }^{+}\end{array}$ & $\begin{array}{l}\text { Radiation grafting: electron beam irradiation of polymer, grafted with vinyl benzene chloride } \\
\text { (VBC) and subsequent quaternisation with trimethylamine. }\end{array}$ & [28-35] \\
\hline Partially fluorinated base polymers such ETFE & Fluorinated monomers: & $\begin{array}{l}\text { Radiation grafting: } \gamma \text {-ray irradiation of polymer, grafting of vinyl monomers containing } \\
\text { desired functional groups (A/B/C), and (where required) susequent quaternisation / amination } \\
\text { to introduce anion-exchange groups into the grafted polymeric chains. }\end{array}$ & [119-120] \\
\hline Base polymer such as ETFE, LDPE etc. & $\begin{array}{l}\text { Sidegroups (post sulfonation and amination): } \\
-\mathrm{SO}_{2}-\mathrm{NR}^{1}-\mathrm{Q}^{+} \text {, preferred below (no hydrogen in } \\
\text { beta position) } \\
\text { Examples: } \\
\text { Trimethylamine; } \\
\mathrm{N}, \mathrm{N}, 2,2 \text {-tetramethyl-1,3-propanediamine; } \\
\mathrm{N}, \mathrm{N}-\text { dimethyl-1,3-propanediamine; } \\
\text { propanediamerazine;2,2-dimethyl-1,3- } \\
\end{array}$ & $\begin{array}{l}\text { Radiation grafting: grafting of styrene/divinylbenzene (DVB) mixtures followed by } \\
\text { chlorosulfonation (to give sulfonate groups), subsequent aminatation using diamines or } \\
\text { polyamines. } \\
\text { Radiation grafting: grafting of vinylbenzylchloride (VBC) / divinylbenzene followed by } \\
\text { amination. }\end{array}$ & {$[80-81]$} \\
\hline Base polymer such as ETFE, LDPE etc. & $\begin{array}{l}\text { Amination agents: } \\
\text { Trimethylamine (TMA), triethylamine (TEA), } \\
\text { dimethylformamide (DMF), 2-chloroacetamide } \\
\text { (2-CA) }\end{array}$ & $\begin{array}{l}\text { Radiation grafting: } \gamma \text {-rays irradiation of polymer, grafted with vinyl benzene chloride (VBC) } \\
\text { or vinyl pyridine (VPy) with subsequent amination. }\end{array}$ & {$[121-122]$} \\
\hline Nafion-F & Active functional groups: & Sythesized via a microwave process using Nafion-F and phosphatranium chloride. & [82] \\
\hline
\end{tabular}




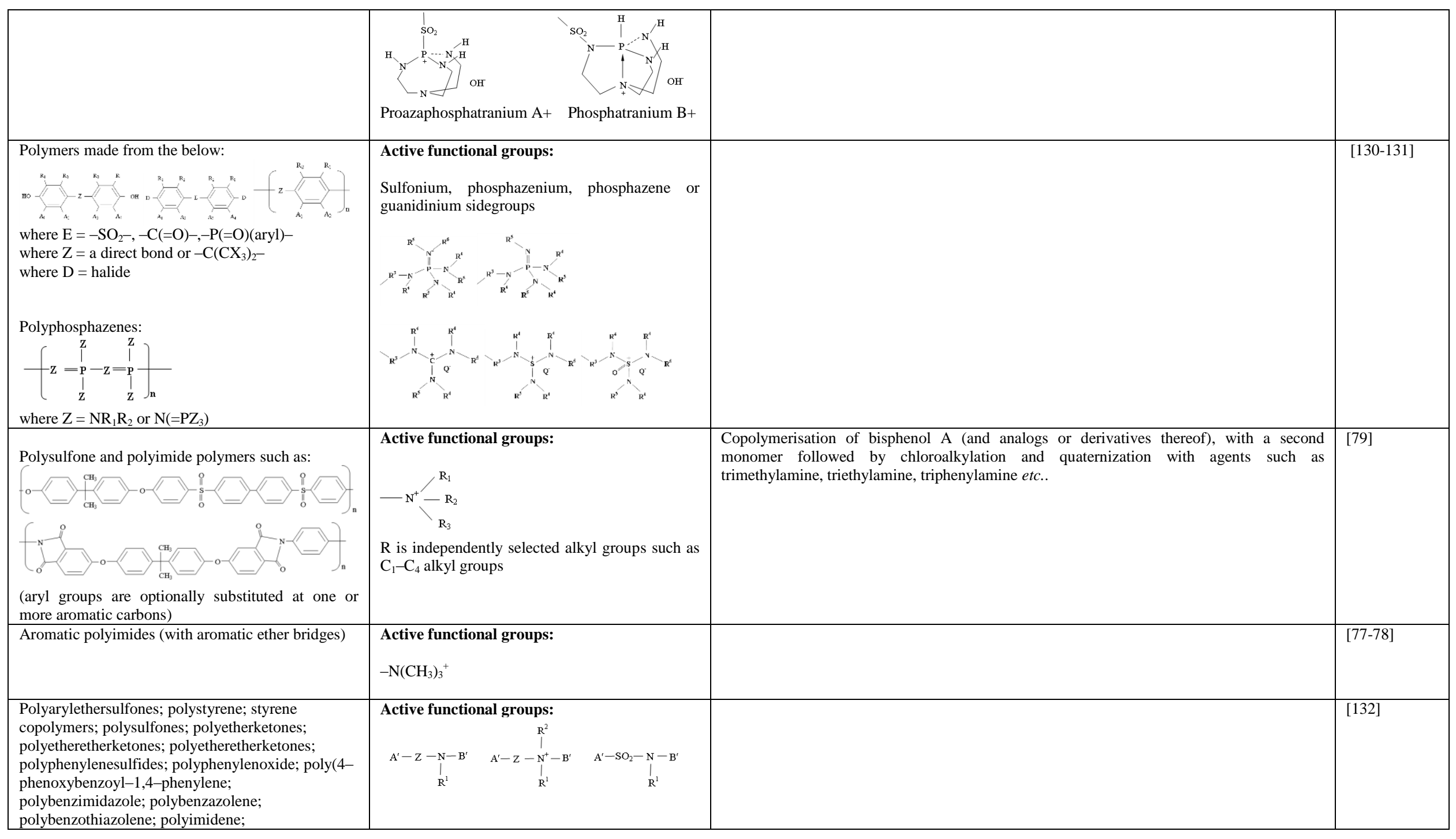




\begin{tabular}{|c|c|c|c|}
\hline $\begin{array}{l}\text { polyphenylenene; polythiophenylenene; } \\
\text { polyphenylenchinoxalinene; polyphosphazenes }\end{array}$ & & & \\
\hline $\begin{array}{l}\text { Aromatic polyethersulfones and polyetherketones: } \\
\text { where } \mathrm{X} \text { and } \mathrm{Y} \text { are }-\mathrm{SO}_{2}-\text { or }-\mathrm{C}(=\mathrm{O}) \text { - links }\end{array}$ & $\begin{array}{l}\text { Active functional groups: } \\
-\mathrm{SO}_{2} \mathrm{~N}\left(\mathrm{R}^{1}\right)-\mathrm{G}-\mathrm{N}^{+} \mathrm{R}_{3}^{2} \\
\text { preferably: } \\
\mathrm{R}^{1} \text { is } \mathrm{H} \text { or an alkyl group bearing a hydrophilic } \\
\text { substituent }\left[\text { e.g. }\left(\mathrm{CH}_{2}\right)_{\mathrm{m}} \mathrm{OH} \text {, where } \mathrm{m} \text { is typically }\right. \\
\text { 2); } \\
\mathrm{R}^{2} \text { is methyl or an alkyl group of up to } 5 \text { carbon } \\
\text { atoms; } \\
\mathrm{G} \text { is an alkylene link containing less than } 4 \\
\text { carbon atoms. } \\
\text { For example: } 1 \text {-amino-3-dimethylaminopropane }\end{array}$ & $\begin{array}{l}\text { After sulfonation, the tertiary amine group was introduced into the backbone of the polymer } \\
\text { and then quaternization using methyl iodide. }\end{array}$ & [83] \\
\hline Poly(phthalazinone ether ketone): & $\begin{array}{l}\text { Active functional groups: } \\
-\mathrm{N}\left(\mathrm{CH}_{3}\right)_{3}^{+}\end{array}$ & Synthesized by the chloromethylation and quaternization of poly(phthalazinone ether ketone). & [133] \\
\hline DAPP-TMPP copolymer & $\begin{array}{l}\text { Active functional groups: } \\
\text { DAPP-ATMPP copolymer }\end{array}$ & & [73] \\
\hline Polysulfone & $\begin{array}{l}\text { Active functional groups: } \\
-\mathrm{N}\left(\mathrm{CH}_{3}\right)_{3}{ }^{+}\end{array}$ & & {$[6,134]$} \\
\hline Polysulfone & $\begin{array}{l}\text { Quaternisation agents: } \\
\text { Trimethylamine(TMA); } \\
\text { N,N,N'N'-tetramethylmethane } \\
\text { diamine(TMMDA); } \\
\text { N,N,N'N'-tetramethylethylene }\end{array}$ & $\begin{array}{l}\text { Polysulfone was chloromethylated quaternized using trimethyamine or tertiary aliphatic } \\
\text { diamines. }\end{array}$ & [96] \\
\hline
\end{tabular}




\begin{tabular}{|c|c|c|c|}
\hline & $\begin{array}{l}\text { diamine(TMEDA); } \\
\text { N,N,N'N'-tetramethyl-1,3-propan } \\
\text { diamine(TMPDA); } \\
\text { N,N,N'N'-tetramethyl-1,4-butane } \\
\text { diamine(TMBDA); } \\
\text { N,N,N'N'-tetramethyl-1,6-hexane } \\
\text { diamine(TMHDA). }\end{array}$ & & \\
\hline Polysulfone & $\begin{array}{l}\text { Active functional groups: } \\
\text { Phosphonium }\end{array}$ & & {$[101]$} \\
\hline Aromatic polyethersulfones & Active functional groups: & $\begin{array}{l}\text { Synthesized via chloromethylation of poly(aryleneether sulfone), followed by amination with } \\
\text { pentamethylguanidine. }\end{array}$ & [98] \\
\hline - 11 & Active functional groups: & & [99] \\
\hline Aromatic polyethersulfones & $\begin{array}{l}\text { Active functional groups: } \\
-\mathrm{N}\left(\mathrm{CH}_{3}\right)_{3}{ }^{+} \text {with bicarbonate anions }\end{array}$ & $\begin{array}{l}\text { Bromination of tetramethyl bisphenol A-based poly(sulfone)s } \\
\text { followed by amination with trimethylamine and ion exchange. }\end{array}$ & [135] \\
\hline $\begin{array}{l}\text { Fluorenyl group containing aromatic polysulfone } \\
\text { and polyketone copolymers: }\end{array}$ & $\begin{array}{l}\text { Active functional groups: } \\
-\mathrm{N}\left(\mathrm{CH}_{3}\right)_{3}{ }^{+}\end{array}$ & $\begin{array}{l}\text { Poly(arylene ether sulfone ketone) bearing fluorenyl groups was synthesized by a } \\
\text { nucleophilic substitution polymerization of 4-fluorophenyl sulfone, 4,4'- } \\
\text { difluorophenylbenzophenone,and 9,9'-bis(4-hydroxyphenyl)-fluorene in the presence of } \\
\text { potassium carbonate in dry N,N'-dimethylacetamide. Subsequent chloromethylation and } \\
\text { animation. }\end{array}$ & [97] \\
\hline Cardo polyethersulfone: & $\begin{array}{l}\text { Active functional groups: } \\
-\mathrm{N}\left(\mathrm{CH}_{3}\right)_{3}^{+}\end{array}$ & $\begin{array}{l}\text { Cardo polyethersulfone was chloromethylated and quaternized with trimethylamine and ion } \\
\text { exchange with sodium hydroxide. }\end{array}$ & {$[136]$} \\
\hline Polyethersulfones $\quad$ containing monofluorinated & Active functional groups: & Fluorinated poly(arylene ether sulfone)s with pendant quaternary ammonium groups were & [104] \\
\hline
\end{tabular}




\begin{tabular}{|c|c|c|c|}
\hline aromatic groups: & $-\mathrm{N}\left(\mathrm{CH}_{3}\right)_{3}{ }^{+}$ & $\begin{array}{l}\text { prepared by copolymerization of } 2,2^{\prime} \text {-dimethylaminemethylene-4,4'-biphenol (DABP), } \\
4,4^{\prime}-\text { biphenol, and } 3,3^{\prime}, 4,4^{\prime}-\text {-tetrafluorodiphenylsulfone, followed by quaternisation with } \\
\text { iodomethane. }\end{array}$ & \\
\hline Partially fluorinated aromatic polyethersulfones: & $\begin{array}{l}\text { Active functional groups: } \\
-\mathrm{N}\left(\mathrm{CH}_{3}\right)_{3}{ }^{+}\end{array}$ & 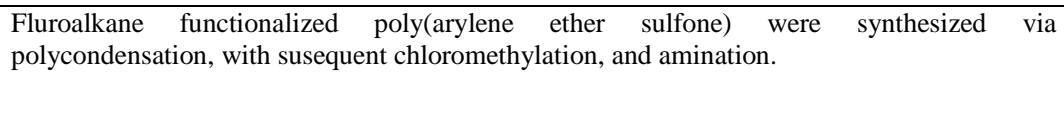 & [105] \\
\hline Sequence-type copolymers of propylene and styrene & $\begin{array}{l}\text { Active functional groups: } \\
\text { where } \mathrm{R}_{1}-\mathrm{R}_{5} \text { are each alkyls of } 1-4 \text { carbon } \\
\text { atoms. }\end{array}$ & $\begin{array}{l}\text { The copolymer was formed using cationic polymerization followed by chloromethylation } \\
\text { (mainly on aromatic rings) and then reacted with a tertiary amines for quaternisation. }\end{array}$ & [95] \\
\hline $\begin{array}{l}\text { Aliphatic polymers containing ether groups in the } \\
\text { backbone: } \\
\left.-\mathrm{CR}_{1} \mathrm{R}_{2}-\mathrm{CR}_{3} \mathrm{R}_{4}-\mathrm{O}\right\}_{\mathrm{n}} \\
\text { Preferably polyepichlorhydrine }\end{array}$ & $\begin{array}{l}\text { Quaternisation agents: } \\
\text { 1,4-diazabicyclo-(2,2,2)-octane }\end{array}$ & $\begin{array}{l}\text { The reactive polymer with halogen-containing functional groups were reacted with tertiary } \\
\text { amine and mixed with inert polymers such as polysulfone, polyethersulfone, } \\
\text { polymethacrylonitrile, polyacrylonitrile and copolymers of the respective monomer unit } \\
\text { (preferably polyacrylonitrile). }\end{array}$ & [137-138] \\
\hline Chitosan derivatives: & $\begin{array}{l}\text { Active functional groups: } \\
-\mathrm{N}\left(\mathrm{CH}_{3}\right)_{3}{ }^{+}\end{array}$ & $\begin{array}{l}\text { The quaternized chirosan derivatives were synthesized using glycidyltrimethylammonium } \\
\text { chloride as the main quaternization reagent and ion-exchanged into the hydroxide form. The } \\
\text { resultant hydroxide-form QCD gels were further cross-linked into anion-exchange } \\
\text { membranes using ethylene glycol diglycidyl ether (EGDE). }\end{array}$ & [139] \\
\hline $\begin{array}{l}\text { Copolymer of vinyl alcohol and a nitrogen-- } \\
\text { containing vinyl monomer such as 4-vinylpyridine }\end{array}$ & & & [140] \\
\hline $\begin{array}{l}\text { Polystyrene-block-poly(ethylene-ran-butylene)- } \\
\text { block-polystyrene: }\end{array}$ & $\begin{array}{l}\text { Active functional groups: } \\
-\mathrm{N}\left(\mathrm{CH}_{3}\right)_{3}{ }^{+}\end{array}$ & $\begin{array}{l}\begin{array}{l}\text { Polystyrene-block-poly(ethylene-ran-butylene)-block-polystyrene } \\
\text { chloromethylated and quaternized. }\end{array} \\
\text { (SEBS) }\end{array}$ & [75] \\
\hline
\end{tabular}




\begin{tabular}{|c|c|c|c|}
\hline 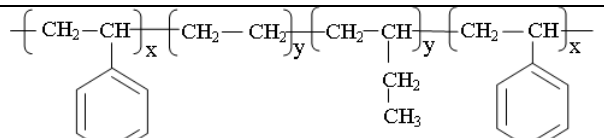 & & & \\
\hline Copolymer of 4-vinylpyridine and styrene & Active functional groups: & & [86] \\
\hline $\begin{array}{l}\text { Photochemical cross-linked } \text { polyepichlorhydrin } \\
\text { with a polyamide support }\end{array}$ & $\begin{array}{l}\text { Quaternisation agents: } \\
\text { 1,4-diazabicyclo-[2,2,2]-octane (DABCO) } \\
\text { 1-azabicyclo-[2,2,2]-octane (Quinuclidine) }\end{array}$ & & [89] \\
\hline Cross-linked quaternized-chitosan & $\begin{array}{l}\text { Active functional groups: } \\
-\mathrm{N}\left(\mathrm{CH}_{3}\right)_{3}{ }^{+}\end{array}$ & & {$[141]$} \\
\hline $\begin{array}{lccc}\text { Cross-Linked } & \text { poly(vinyl } & \text { alcohol) } & \text { and } \\
\text { poly(acrylonitrile-co-2- } & & \\
\text { dimethylaminoethylmethacrylate) copolymer } & \end{array}$ & $\begin{array}{l}\text { Active functional groups: } \\
-\mathrm{N}\left(\mathrm{CH}_{3}\right)_{3}{ }^{+}\end{array}$ & & {$[142]$} \\
\hline $\begin{array}{l}\text { Poly(vinyl alcohol)-silica inorganic-organic hybrid } \\
\text { matrix }\end{array}$ & Reactive monomer: & $\begin{array}{l}\text { Sol-gel reaction of quaternized poly(vinyl alcohol) with various ratios of tetraethoxysilanes } \\
\text { (TEOS). }\end{array}$ & {$[113-114]$} \\
\hline $\begin{array}{l}\text { Aliphatic hydrocarbon - inorganic oxide hybrid } \\
\text { matrix }\end{array}$ & $\begin{array}{l}\text { Active functional groups: } \\
\text { Alkyl and heterocyclic quaternary ammonium } \\
\text { salt; a metal hydroxide salts, preferably with } \\
\text { aluminium hydroxides }\left(\left[\mathrm{AlX}(\mathrm{OH})_{3}\right]^{-} \text {and }\right. \\
\left.\left[\mathrm{Al}_{2} \mathrm{X}(\mathrm{OH})_{6}\right]^{-}\right) \text {. }\end{array}$ & & {$[143]$} \\
\hline
\end{tabular}




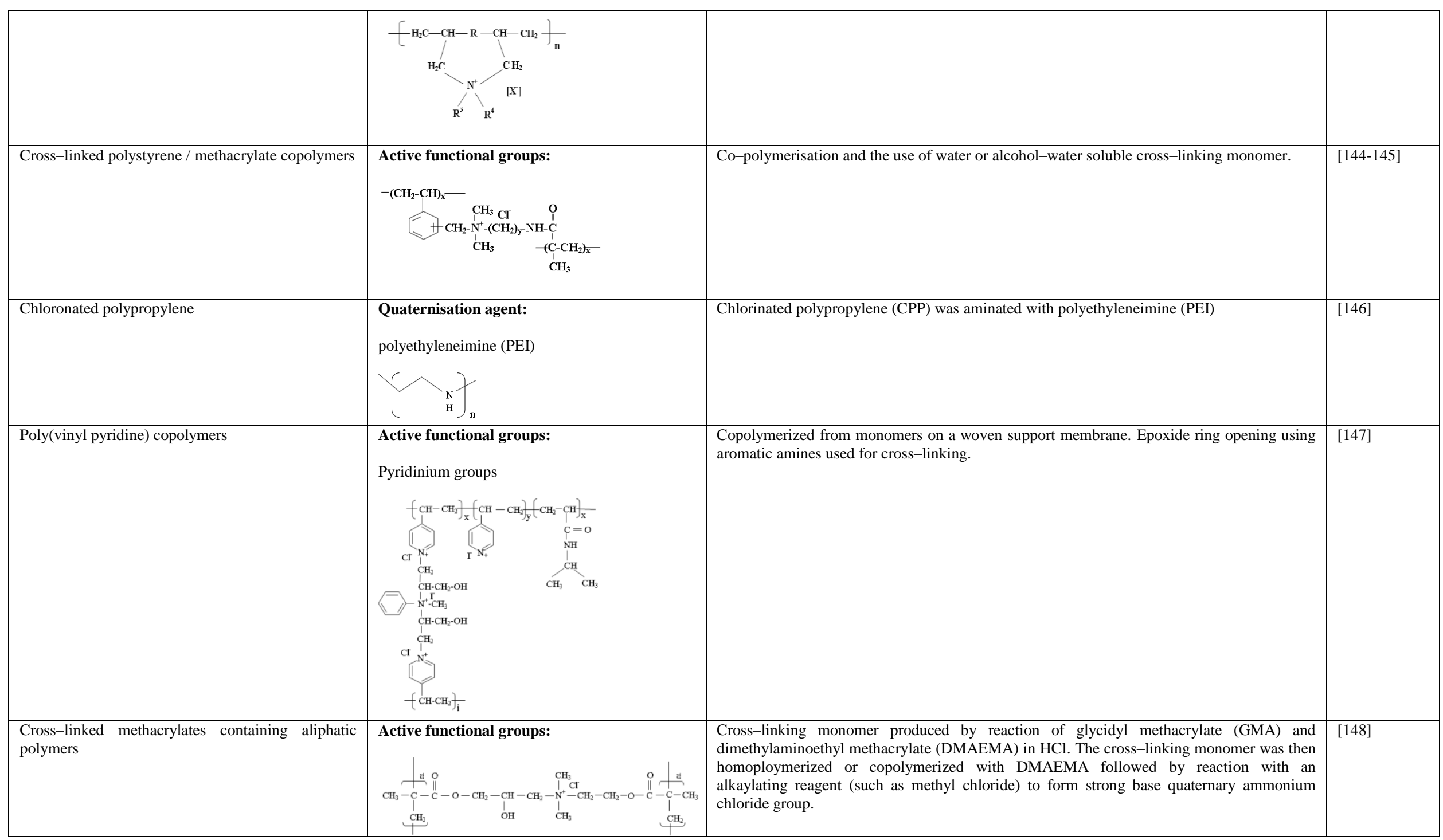




\begin{tabular}{|c|c|c|c|}
\hline $\begin{array}{l}\text { Polymethylimidalolium "ionic liquid polymer" } \\
\text { copolymerized with methacrylate }\end{array}$ & 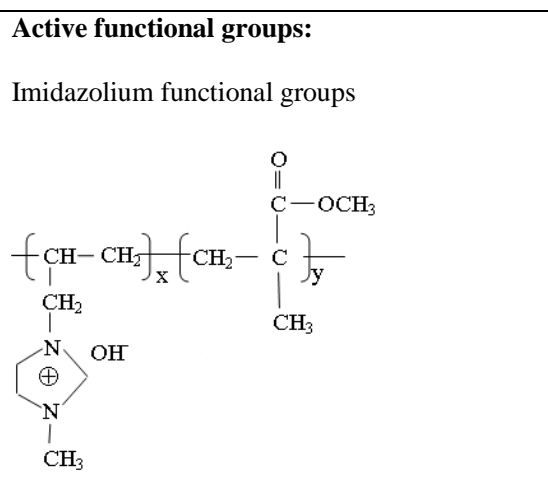 & $\begin{array}{l}\text { Free radical polymerization of 1-allyl-3-methylimidazolium chloride ionic liquid either with } \\
\text { methyl methacrylate or butyl methacrylate. }\end{array}$ & [103] \\
\hline $\begin{array}{l}\text { Cross-linked aliphatic polymers containing vinyl } \\
\text { groups in the backbone }\end{array}$ & Active functional groups: & Ring opening metathesis polymerization to generate cross-linked membranes & [93] \\
\hline $\begin{array}{l}\text { Cross-linked cyclic aliphatic polymers containing } \\
\text { vinyl groups in the backbone. }\end{array}$ & $\begin{array}{l}\text { Highly functionalized monomer: } \\
\qquad \mathrm{I}-\mathrm{N}^{+} \mathrm{Me}_{3}\end{array}$ & $\begin{array}{l}\text { Ring-opening metathesis polymerization of a tetraalkylammonium-functionalized } \\
\text { norbornene with dicyclopentadiene as a cross-linkable co-monomer. }\end{array}$ & [116] \\
\hline $\begin{array}{l}\text { Tetraalkylammonium-functionlized } \\
\text { polyethylene }\end{array}$ & Highly functionalized monomer: & $\begin{array}{l}\text { Ring-opening metathesis polymerization followed by hydrogenation to remove the } \mathrm{C}=\mathrm{C} \\
\text { bonds to generate tetraalkylammonium-functionlized polyethylene. }\end{array}$ & [117] \\
\hline $\begin{array}{l}\text { Poly(phenylene oxide) - silica organic-inorganic } \\
\text { hybrid polymers } \\
\qquad \mathrm{CH}_{3}\end{array}$ & $\begin{array}{l}\text { Active functional groups: } \\
-\mathrm{N}\left(\mathrm{CH}_{3}\right)_{3}{ }^{+} \text {and }-\mathrm{N}\left(\mathrm{CH}_{2} \mathrm{CH}_{3}\right)_{3}^{+} \text {groups }\end{array}$ & $\begin{array}{l}\text { PPO is modified by bromination, hydroxylation and quaternization. Subsequent sol-gel } \\
\text { reaction with monophenyl triethoxysilane (EPh) and tetraethoxysilane (TEOS) followed by } \\
\text { heat treatment at } 120-140{ }^{\circ} \mathrm{C} \text { yields the hybrid membranes. }\end{array}$ & {$[107-109]$} \\
\hline Polysiloxane & Active functional groups: & Sol-gel synthesis method & {$[110,115]$} \\
\hline
\end{tabular}




\begin{tabular}{|c|c|c|c|}
\hline & $-\mathrm{N}\left(\mathrm{CH}_{3}\right)_{3}{ }^{+}$ & & \\
\hline $\begin{array}{l}\text { Polyethylene oxide (PEO)-silica organic-inorganic } \\
\text { hybrid membranes }\end{array}$ & $\begin{array}{l}\text { Active functional groups: } \\
\text { poly-N(}\left(\mathrm{CH}_{3}\right)_{2}{ }^{+} \text {-poly in polymer backbones }\end{array}$ & Sol-gel synthesis method & [111] \\
\hline $\begin{array}{l}\text { Copolymer of vinylbenzyl chloride and } \gamma- \\
\text { methacryloxypropyl trimethoxy silane }\end{array}$ & $\begin{array}{l}\text { Active functional groups: } \\
-\mathrm{N}\left(\mathrm{CH}_{3}\right)_{3}^{+}\end{array}$ & $\begin{array}{l}\text { TMA-quatenized poly(VBC-co- } \gamma \text {-MPS) with subsequent sol-gel process with monophenyl- } \\
\text { triethoxysilane to form the copolymer. }\end{array}$ & [112] \\
\hline $\begin{array}{l}\text { Cross-linked poly(vinyl alcohol)-silica organic- } \\
\text { inorganic hybrid membrane }\end{array}$ & Active functional groups: & $\begin{array}{l}\text { Organic-inorganic anion-exchange silica precursor (AESP) synthesized using 3-(2- } \\
\text { aminoethylamino)propyltrimethoxysilane and glycidoxypropyltrimethylammonium chloride } \\
\text { by epoxide ring opening reaction. Hybrid AEMs were prepared with AESP and PVA by sol- } \\
\text { gel method in aqueous media. }\end{array}$ & [106] \\
\hline
\end{tabular}


Table 2 Summary of base AAEM properties

\begin{tabular}{|c|c|c|c|c|c|}
\hline 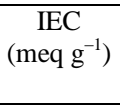 & $\begin{array}{l}\text { Ion conductivity* } \\
\quad\left(\mathrm{mS} \mathrm{cm}^{-1}\right)\end{array}$ & $\begin{array}{l}\text { Water } \\
\text { uptake } \\
(\%)\end{array}$ & $\begin{array}{l}\text { Peak power density** } \\
\qquad\left(\mathrm{mW} \mathrm{cm}^{-2}\right)\end{array}$ & $\begin{array}{c}\text { Methanol } \\
\text { permeability } \\
\left(\times 10^{-7} \mathrm{~cm}^{2} \mathrm{~s}^{-1}\right) \\
\end{array}$ & References \\
\hline- & $\begin{array}{c}68.7\left(20^{\circ} \mathrm{C}\right) \\
111\left(50^{\circ} \mathrm{C}\right) \\
158\left(90^{\circ} \mathrm{C}\right) \\
28\left(50^{\circ} \mathrm{C} \text { in } \mathrm{CO}_{3}{ }^{2-}\right) \\
\end{array}$ & - & - & - & [93] \\
\hline 2.88 & $84\left(20^{\circ} \mathrm{C}\right)$ & $179\left(20^{\circ} \mathrm{C}\right)$ & - & - & [104] \\
\hline 2.62 & $65\left(20^{\circ} \mathrm{C}\right)-87\left(60^{\circ} \mathrm{C}\right)$ & $\begin{array}{l}86\left(20^{\circ} \mathrm{C}\right)- \\
253\left(60^{\circ} \mathrm{C}\right)\end{array}$ & & & \\
\hline 1.76 & $75.7\left(30^{\circ} \mathrm{C}\right)$ & 55.6 & - & $\begin{array}{l}\text { 4.12(30\%methanol) } \\
6.66(50 \% \text { methanol })\end{array}$ & [106] \\
\hline- & $\begin{array}{l}10\left(25^{\circ} \mathrm{C}, \mathrm{CO}_{3}{ }^{2-}\right) \\
63\left(70^{\circ} \mathrm{C}, \mathrm{CO}_{3}{ }^{2-}\right)\end{array}$ & & $4\left(25^{\circ} \mathrm{C}, \mathrm{H}_{2} / \mathrm{O}_{2}+\mathrm{CO}_{2}\right)$ & - & {$[105]$} \\
\hline- & $\begin{array}{c}41(\mathrm{RT})-92\left(70^{\circ} \mathrm{C}\right) \\
\text { measured in } \\
\mathrm{NaOH}\left(\mathrm{aq}, 1 \mathrm{~mol} \mathrm{dm}^{-3}\right) \\
\end{array}$ & & - & $0.572-1.23$ & {$[136]$} \\
\hline 2.54 & $50\left(30^{\circ} \mathrm{C}\right)-78\left(60^{\circ} \mathrm{C}\right)$ & 160 & - & - & [97] \\
\hline 1.89 & $45\left(20^{\circ} \mathrm{C}\right), 74\left(60^{\circ} \mathrm{C}\right)$ & $\begin{array}{l}55\left(20^{\circ} \mathrm{C}\right), \\
107\left(60^{\circ} \mathrm{C}\right)\end{array}$ & - & - & [98] \\
\hline 2.15 & $67\left(20^{\circ} \mathrm{C}\right)$ & $88\left(20^{\circ} \mathrm{C}\right)$ & & & \\
\hline 0.22 & $33.3\left(30^{\circ} \mathrm{C}\right)-65.7\left(90^{\circ} \mathrm{C}\right)$ & - & - & $\sim 10^{-2}$ & [103] \\
\hline & $\begin{array}{c}46\left(\text { in } \mathrm{OH}^{-}\right) \\
12\left(\text { in } \mathrm{HCO}_{3}^{-}\right) \\
\end{array}$ & - & - & - & {$[135]$} \\
\hline 1.2 & 45 & & $225\left(50^{\circ} \mathrm{C}, 250 \mathrm{kPa}\right)$ & & {$[101]$} \\
\hline $1.4-1.6$ & $34\left(50^{\circ} \mathrm{C}\right)$ & - & $130\left(50^{\circ} \mathrm{C}, \mathrm{Pt} / \mathrm{C}\right)$ & - & [34-35] \\
\hline 1.4 & $\begin{array}{l}18\left(20^{\circ} \mathrm{C}\right) \\
28\left(50^{\circ} \mathrm{C}\right)\end{array}$ & - & - & - & {$[116]$} \\
\hline $\begin{array}{l}1.18 \\
1.08\end{array}$ & $\begin{array}{l}32\left(60^{\circ} \mathrm{C}\right) \\
17\left(60^{\circ} \mathrm{C}\right)\end{array}$ & - & $\sim 110\left(60^{\circ} \mathrm{C}\right)$ & - & {$[134]$} \\
\hline- & $11.4\left(80^{\circ} \mathrm{C}\right)$ & - & $\begin{array}{c}7.76 \mu \mathrm{W} \mathrm{cm}{ }^{-2} \\
\text { Methanol fuel } \\
\text { No ionic interface } \\
\end{array}$ & 6.57 & [133] \\
\hline 0.3 & $9.37\left(80^{\circ} \mathrm{C}\right)$ & - & - & $2.34-4.45$ & {$[75]$} \\
\hline- & 10 & - & $\begin{array}{c}30.1\left(\mathrm{H}_{2} / \mathrm{Air}\right) \\
\mathrm{Pt} / \mathrm{C} \text { anode } \\
\mathrm{Ag} / \mathrm{C} \text { cathode }\end{array}$ & - & [96] \\
\hline 0.86 & ca. 10 & - & - & - & [139] \\
\hline- & $8\left(25^{\circ} \mathrm{C}\right)$ & - & $\begin{array}{c}1.5\left(45^{\circ} \mathrm{C}, 1 \mathrm{~mol} \mathrm{dm}{ }^{-3}\right. \\
\left.\text { methanol } / \mathrm{O}_{2}\right)\end{array}$ & - & {$[86]$} \\
\hline 1.18 & $\begin{array}{c}\text { 3.45(in } 0.05 \mathrm{~mol} \mathrm{dm}^{-3} \\
\mathrm{NaCl} \text { ) }\end{array}$ & - & & - & {$[142]$} \\
\hline 1.3 & $\begin{array}{c}2.5\left(20^{\circ} \mathrm{C}\right) ; 13\left(60^{\circ} \mathrm{C}\right) \\
75\left(25^{\circ} \mathrm{C}, \text { in } 2.5 \mathrm{~mol} \mathrm{dm}^{-3}\right. \\
\mathrm{KOH})\end{array}$ & - & $\begin{array}{c}>100\left(25^{\circ} \mathrm{C}\right) \\
\mathrm{KOH}\left(\mathrm{aq}, 7 \mathrm{~mol} \mathrm{dm}^{-3}\right) \\
\text { applied on surface of } \\
\text { membrane })\end{array}$ & - & [89] \\
\hline 0.57 & $\begin{array}{c}3.46\left(30^{\circ} \mathrm{C}\right) \\
14\left(60^{\circ} \mathrm{C}\right)\end{array}$ & 167 & - & $8.45-11.6\left(30^{\circ} \mathrm{C}\right)$ & {$[114]$} \\
\hline- & 7.5 & - & $24\left(50^{\circ} \mathrm{C}, \mathrm{H}_{2} /\right.$ Air, $\left.241 \mathrm{kPa}\right)$ & - & {$[141]$} \\
\hline- & $\begin{array}{c}0.1\left(80^{\circ} \mathrm{C} \text {, under }\right. \\
\left.\text { humidified } \mathrm{O}_{2} \text { gas flow }\right)\end{array}$ & - & $0.76\left(40^{\circ} \mathrm{C}\right)$ & - & {$[115]$} \\
\hline $\begin{array}{l}7.38- \\
9.33\end{array}$ & $\begin{array}{c}\text { 8.9-13.6(immersed in } \\
0.1 \mathrm{~mol} \mathrm{dm}^{-3} \mathrm{NaCl} \text { before } \\
\text { test) }\end{array}$ & 32 & & - & {$[146]$} \\
\hline
\end{tabular}

* Ion conductivity is tested in water unless specified.

** In $\mathrm{H}_{2} / \mathrm{O}_{2}$ unless otherwise indicated. 
Table 3 Summary of Membrane Electrode Assemblies in Tokuyama patent EP1965456

\begin{tabular}{|c|c|c|c|c|c|c|}
\hline & \multirow{2}{*}{$\begin{array}{l}\text { Membrane } \\
\text { composition } \\
\text { forming a for } \\
\text { electrolyte } \\
\text { membrane }\end{array}$} & \multicolumn{2}{|c|}{ Intermediate layer composition } & \multicolumn{2}{|c|}{$\begin{array}{l}\text { Electrode membrane } \\
\text { composition(parts by weight) }\end{array}$} & \multirow[t]{2}{*}{$\begin{array}{l}\text { Quaternarizing } \\
\text { agent }\end{array}$} \\
\hline & & $\begin{array}{l}\text { Bifunctional } \\
\text { quaternarizing } \\
\text { agent }\end{array}$ & Organic solvent & $\begin{array}{l}\text { Organic } \\
\text { compound for } \\
\text { forming an ion } \\
\text { exchange resin }\end{array}$ & Organic solvent & \\
\hline $2-1$ & $\begin{array}{l}\text { chloromethylstyrene } \\
\text {-divinylbenzene } \\
\text { copolymer }\end{array}$ & $\begin{array}{l}\text { N,N,N',N'- } \\
\text { tetramethyl-1,6- } \\
\text { hexanediamine(5) }\end{array}$ & $\begin{array}{l}\text { Tetrahydrofuran } \\
\text { (15) }\end{array}$ & $\begin{array}{l}\text { chloromethylstyr } \\
\text { ene-styrene } \\
\text { copolymer( } 80)\end{array}$ & $\begin{array}{l}\text { Tetrahydrofuran } \\
\text { (20) }\end{array}$ & trimethylamine \\
\hline $2-2$ & $\begin{array}{l}\text { vinylpyridine- } \\
\text { divinylbenzene } \\
\text { copolymer }\end{array}$ & $\begin{array}{l}1,6- \\
\text { diiodohexane(5) }\end{array}$ & $\begin{array}{l}\text { Tetrahydrofuran } \\
\text { (15) }\end{array}$ & $\begin{array}{l}\text { vinylpyridine-- } \\
\text { styrene } \\
\text { copolymer }(80]\end{array}$ & $\begin{array}{l}\text { Tetrahydrofuran } \\
\text { (20) }\end{array}$ & methyl iodide \\
\hline
\end{tabular}

